\title{
Versterking van de loopbaanladder van leraren : wat kunnen we leren van Singapore?
}

Citation for published version (APA):

Elffers, L. (2015). Versterking van de loopbaanladder van leraren : wat kunnen we leren van Singapore? ROA. ROA Technical Reports No. 007 https://doi.org/10.26481/umarot.2015007

Document status and date:

Published: 01/01/2015

DOI:

10.26481/umarot.2015007

Document Version:

Publisher's PDF, also known as Version of record

\section{Please check the document version of this publication:}

- A submitted manuscript is the version of the article upon submission and before peer-review. There can be important differences between the submitted version and the official published version of record.

People interested in the research are advised to contact the author for the final version of the publication, or visit the DOI to the publisher's website.

- The final author version and the galley proof are versions of the publication after peer review.

- The final published version features the final layout of the paper including the volume, issue and page numbers.

Link to publication

\footnotetext{
General rights rights.

- You may freely distribute the URL identifying the publication in the public portal. please follow below link for the End User Agreement:

www.umlib.nl/taverne-license

Take down policy

If you believe that this document breaches copyright please contact us at:

repository@maastrichtuniversity.nl

providing details and we will investigate your claim.
}

Copyright and moral rights for the publications made accessible in the public portal are retained by the authors and/or other copyright owners and it is a condition of accessing publications that users recognise and abide by the legal requirements associated with these

- Users may download and print one copy of any publication from the public portal for the purpose of private study or research.

- You may not further distribute the material or use it for any profit-making activity or commercial gain

If the publication is distributed under the terms of Article $25 \mathrm{fa}$ of the Dutch Copyright Act, indicated by the "Taverne" license above, 


\section{Versterking van de loopbaanladder van leraren: wat kunnen we leren van Singapore?}

Louise Elffers

\section{ROA Technical Report}

ROA-TR-2015/7

Researchcentrum voor Onderwijs en Arbeidsmarkt | ROA Research Centre for Education and the Labour Market | ROA 


\section{Versterking van de loopbaanladder van leraren: wat kunnen we leren van Singapore?}

Louise Elffers

ROA-TR-2015/7

November 2015

Research Centre for Education and the Labour Market Maastricht University

P.O. Box 616, 6200 MD Maastricht, The Netherlands

$\mathrm{T}+31433883647 \mathrm{~F}+31433884914$

secretary-roa-sbe@maastrichtuniversity.nl www.roa.nl 
Versterking van de loopbaanladder van leraren: wat kunnen we leren van Singapore?

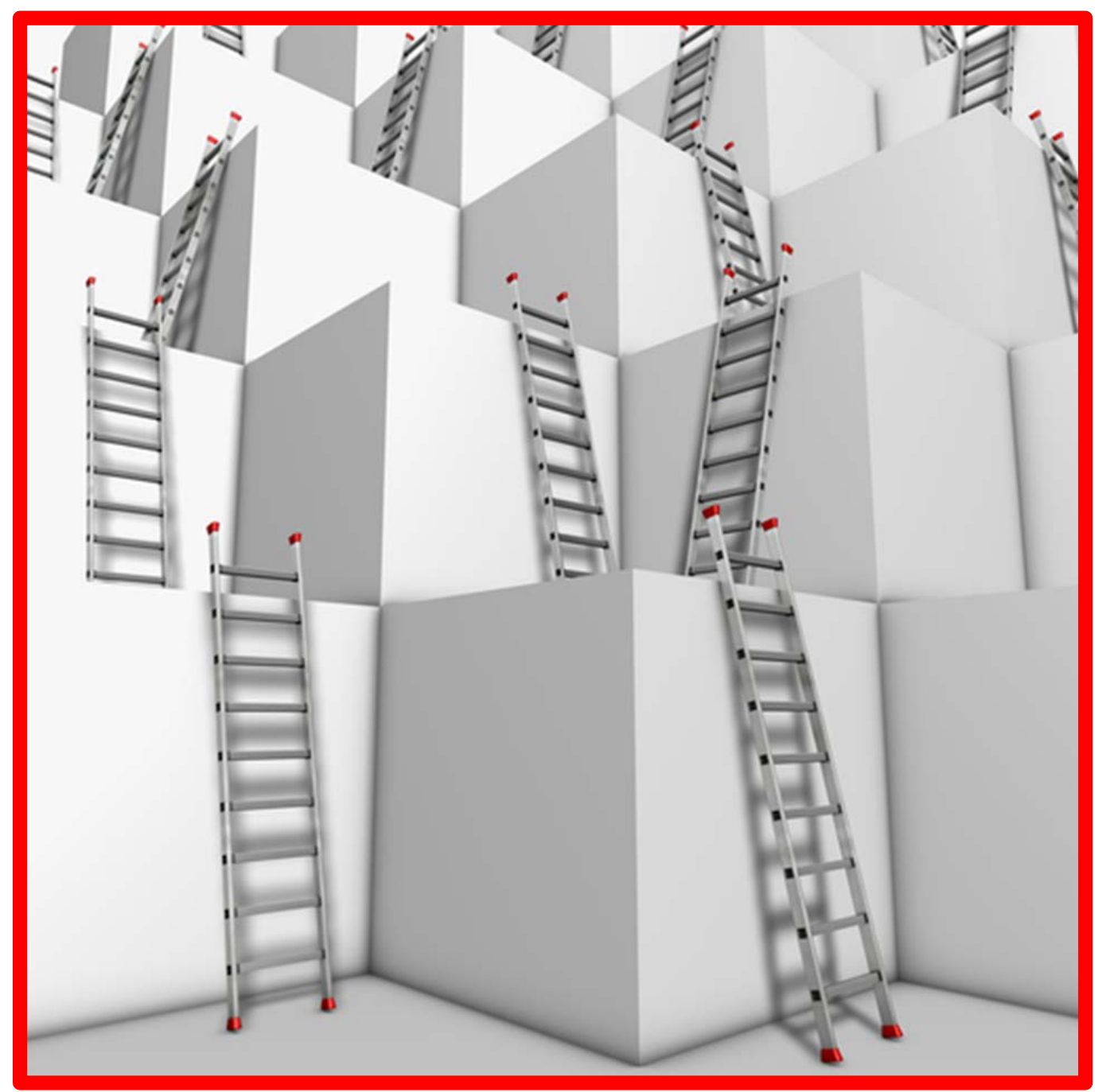

Verkennend onderzoek voor het Ministerie van OCW Eindrapportage, juni 2015

Dr. Louise Elffers

Academische Werkplaats Onderwijs / ROA

Universiteit Maastricht 


\section{Samenvatting}

In de Lerarenagenda 2013-2020 is een aantal doelstellingen geformuleerd ten aanzien van de bevordering van de loopbaan en professionele ontwikkeling van leraren. Enerzijds wordt ingezet op het stimuleren van professionalisering van leraren na hun initiële opleiding, anderzijds op het versterken van carrièreperspectieven van aankomende en reeds werkende leraren. Met enige regelmaat wordt in dit licht de loopbaanladder van leraren in Singapore aangehaald als aantrekkelijk en succesvol voorbeeld. In dit rapport wordt het Singaporese model nader beschreven, waarna wordt verkend in hoeverre dit model, of aspecten daarvan, als voorbeeld zou kunnen dienen bij het realiseren van beleidsdoelstellingen gericht op de blijvende bekwaamheid en loopbaanperspectieven van Nederlandse leraren. Ten behoeve van deze verkenning is gesproken met verschillende betrokkenen in Singapore en in Nederland.

Uit de verkenning komen enkele leerpunten naar voren die Nederland zou kunnen benutten bij het uitwerken van de beleidsagenda. Deze leerpunten betreffen, in hoofdlijnen, het ontwikkelen van een integrale visie op de professionele ontwikkeling van leraren met een sterke focus op vraagsturing, gerichte nascholingsprogramma's die aansluiten bij de loopbaanfase, functie en leervragen van de leraar, structurele persoonlijke begeleiding voor leraren bij het vormgeven van hun professionele ontwikkeling, en het positioneren van professionele ontwikkeling van leraren als een recht in plaats van een plicht. De Singaporese loopbaanladder van leraren biedt daarvoor een duidelijke routekaart, met herkenbare routes en uiteenlopende functies aan de hand waarvan leraren zich kunnen ontwikkelen in verschillende richtingen. Met name de positionering van de Teaching Track, met senior functies die gericht zijn op onderwijsontwikkeling en het pedagogisch-didactisch handelen, biedt aanknopingspunten voor de ontwikkeling en verankering van sterk pedagogisch leiderschap van leraren in het Nederlandse onderwijs. 


\section{Inhoudsopgave}

1. Aanleiding voor het onderzoek 4

2. Doelstelling van het onderzoek 6

$\begin{array}{ll}\text { 3. Opzet van het onderzoek } & 7\end{array}$

4. Vooraf: enkele kenmerken van het Singaporese onderwijs 9

5. De Singaporese loopbaanladder van leraren 11

- De drie tracks 11

- De basis: de classroom teacher 11

- De Teaching Track 12

- De Leadership Track. 13

- De Senior Specialist Track 14

- Instromen en opstromen 14

6. Professionele ontwikkeling van leraren in Singapore 17

- Positionering professionele ontwikkeling $\quad 17$

- Het Teacher Growth Model 18

- Aanbod activiteiten 19

- Gestandaardiseerde trajecten 20

- Keuze voor activiteiten $\quad 21$

- Tijd voor professionele ontwikkeling 23

- Kosten van professionele ontwikkeling 24

- Evaluatie opbrengsten van professionele ontwikkeling 24

7. Verkenning leerpunten: wat kan Nederland leren van Singapore? 26

- Doelstelling 1: blijvende bekwaamheid 26

- Doelstelling 2: horizontale versterking loopbaanladder 28

- Doelstelling 3: verticale versterking loopbaanladder 29

- Conclusie 30

Bijlage 1: gesprekspartners Singapore $\quad 33$

Bijlage 2: gesprekspartners Nederland

Aangehaalde literatuur $\quad 35$ 


\section{Aanleiding voor het onderzoek:}

\section{knelpunten in de loopbaanladder en professionalisering van Nederlandse leraren}

\section{Professionele ontwikkeling van leraren}

Goed onderwijs staat of valt met de kwaliteit van de leraren voor de klas. Er gaat dan ook veel aandacht uit naar mogelijkheden om de kwaliteit van leraren in het Nederlandse onderwijs te bevorderen. In de Lerarenagenda 2013 - 2020 is de ambitie uitgesproken dat elke leraar in het PO, VO en MBO "blijvend bekwaam en bevoegd is" (Ministerie van OCW, 2013). Dit houdt in dat een leraar niet alleen in beginsel de juiste kennis en vaardigheden in huis heeft om zijn vak uit te kunnen oefenen, maar ook dat een leraar zijn kennis en vaardigheden continu blijft ontwikkelen. In recente beleidsplannen gaat veel aandacht uit naar verhoging van de kwaliteit van de instroom in het lerarenberoep, onder meer door versterking van het niveau van instromers in het lerarenopleidingen, door kwaliteitsverbetering op de lerarenopleidingen zelf, en door een betere begeleiding van beginnende leraren in de eerste jaren van hun loopbaan (Ministerie van OCW, 2013). Voor de professionele ontwikkeling van leraren ná hun initiële opleiding wordt met name ingezet op persoonlijke scholingsbudgetten, zoals de lerarenbeurs en de promotiebeurs voor leraren. Wat opvalt is dat er geen structurele koppeling bestaat tussen het opleidingsniveau, of het succesvol afronden van aanvullende scholing, en de positionering en beloning van leraren. Er blijkt bijvoorbeeld zelden sprake van een verandering van functie of een hoger salaris na het voltooien van een opleiding met behulp van een lerarenbeurs (IVA, 2012). Het doorgroeiperspectief en de inschaling van leraren is niet gekoppeld aan opleidingstrajecten.

\section{Aantrekkelijke carrièrepaden voor leraren}

Voor een duurzame professionele ontwikkeling van leraren is het van belang dat zittende leraren gedurende hun loopbaan kunnen blijven doorgroeien aan de hand van aantrekkelijke carrièrepaden (Kamerbrief Minister van Onderwijs, 28 oktober 2014). De Commissie Leraren constateerde in 2007 dat het hieraan schort. Het onderwijs kent weinig functiedifferentiatie: weliswaar vervullen twee op de drie leraren een of meer specifieke aanvullende taken, zoals coördinator of stagebegeleider, maar dit gaat meestal om taakdifferentiatie binnen dezelfde functieschaal (Commissie Leraren, 2007). Bovendien zijn schoolorganisaties 'platte organisaties' die weinig kansen bieden voor promotie, tenzij leraren het lesgeven achter zich laten en overstappen naar het management (Gerrichhauzen, 2007; Evers, 2007). Differentiatie op basis van lesgevende of leerlinggerichte kwaliteiten en taken gebeurt zelden (Commissie Leraren, 2007). Doordat er geen onderscheid wordt gemaakt naar opleidingsniveau in de positionering en beloning van leraren, ontbreekt een belangrijke prikkel voor leraren om zich verder te ontwikkelen aan de hand van scholing. Bovendien is het onderwijs voor werknemers met een mastergraad hierdoor minder aantrekkelijk in vergelijking met andere arbeidsmarktsectoren. De onderwijssector wordt dan ook gezien als een tamelijk gesloten sector, waarin weinig interne en externe mobiliteit onder werknemers plaatsvindt. Twee derde van de leraren in het PO en maar liefst driekwart van de leraren in VO en BVE was ten tijde van het uitkomen van het rapport van de Commissie Leraren ontevreden over hun carrièreperspectieven. De Commissie adviseerde daarom een meer expliciete koppeling van het loongebouw an het opleidingsniveau van leraren, met meer ruimte voor beloning van leraren met een hogere kwalificatie.

\section{Versterking van de functiemix}

Deze laatste aanbeveling lijkt voor een deel gerealiseerd met het Convenant Leerkracht van Nederland (2008). Hierin zijn afspraken vastgelegd over de versterking van de functiemix, waardoor meer leraren kunnen promoveren naar een hoger niveau met dito beloning. Dit heeft ertoe geleid dat er meer leraren in een hogere functieschaal zijn aangesteld. Deze afspraken zijn echter niet gekoppeld aan criteria op het gebied 
van scholing, zoals de Commissie Leraren adviseerde. De verantwoordelijkheid voor de versterking van de functiemix ligt bij de schoolbesturen. Zij bepalen zelf welke criteria ze hanteren voor de bevordering van leraren. De overheid stelt via de sectorakkoorden en cao's tijd, geld en ruimte beschikbaar om docenten te faciliteren in hun verdere professionalisering (brief Minister van Onderwijs, Cultuur en Wetenschap, 2014). Daarmee ligt het initiatief voor de verdere professionalisering van leraren na hun initiële opleiding primair bij de individuele leraar en de school waar deze werkzaam is. Op stelselniveau is geen sprake van structurele professionaliseringstrajecten met een bijbehorende functiematrix.

\section{Gebrek aan prikkels voor professionele ontwikkeling}

Het huidige loongebouw voor leraren laat dus wel ruimte om talentvolle leraren beter te belonen, maar er is in termen van positie en beloning geen directe prikkel voor leraren om deel te nemen aan scholing na hun initiële opleiding. Bovendien is, door het gebrek aan koppeling van opleiding en inschaling, het rendement van deelname aan dergelijke professionaliserings-trajecten voor leraren niet helder. Mogelijk is dit een van de redenen waarom Nederlandse leraren veel minder deelnemen aan nascholingsactiviteiten dan leraren in andere landen (Inspectie van het Onderwijs, 2014). Daarnaast is er een gebrek aan mogelijkheden voor leraren om hun functie te verbreden naar andere taken en verantwoordelijkheden, behalve wanneer zij ervoor kiezen het lesgeven achter zich te laten en zich volledig op managementtaken te richten (Evers, 2007). Het gebrek aan doorgroei- en verbredingsmogelijkheden kan een initiële danwel blijvende keuze voor het leraarschap in de weg staan. Het bieden van loopbaantrajecten die de interne mobiliteit in onderwijsorganisaties stimuleert, kan bijdragen aan zowel het verhogen van de kwaliteit van huidige leraren, als aan het werven van talentvolle werknemers in het onderwijs (Gerrichhauzen, 2007).

\section{Naar een brede ontwikkeling en inzetbaarheid van leraren}

Recent gaan er meer geluiden op om het carrièreperspectief van leraren te verbeteren en de professionele ontwikkeling van leraren steviger te verankeren in het loongebouw. Zo suggereerde de Onderwijsraad (2013) om registratie in het lerarenregister te koppelen aan deelname aan bij- en nascholingsactiviteiten. Ook het pamflet Samen Leren (2014) stelt dat leraren zich aantoonbaar moeten blijven ontwikkelen om in het register opgenomen te blijven. Daarmee ontstaat wel een expliciete koppeling tussen scholing en initiële registratie van de leraar, maar niet tussen scholing en verdere doorgroeimogelijkheden van een leraar naar hogere functies en salariëring. Het genoemde pamflet stelt echter ook dat er behoefte is aan meer alternatieve carrièrepaden voor leraren, waarbij leraren al dan niet tijdelijk naar andere functies kunnen overstappen in het onderwijs of daarbuiten. De versterking van de functiemix heeft bijvoorbeeld alleen betrekking op leraren die minimaal $50 \%$ tot $60 \%$ van hun aanstelling voor de klas staan. Leraren die minder lesgeven en meer andere taken, zoals onderwijsontwikkelings- of leidinggevende taken, op zich nemen, vallen daarmee in principe niet onder de regeling. Al langer wordt gesuggereerd dat de loopbaanladder van leraren te eendimensionaal zou zijn. Er is weinig ruimte voor leraren om zich in de breedte te ontwikkelen, door het leraarschap te combineren met andere taken of functies. Dit kan ertoe leiden dat talentvolle individuen die meer kunnen en willen dan enkel lesgeven, niet kiezen voor het leraarschap of na verloop van tijd afhaken. Betere mogelijkheden om het leraarschap te combineren met andere taken zouden enerzijds een gunstige uitwerking kunnen hebben op de kwaliteit van de leraar en het onderwijs in bredere zin, en anderzijds het carrièreperspectief van leraren kunnen verbeteren. Deze gedachte zien we onder andere terug bij programma's als Eerst de Klas en Hybride Docent, waarin het leraarschap wordt gecombineerd met andere verantwoordelijkheden. Horizontale en verticale versterking van de loopbaanladder van leraren kan bijdragen aan een aantrekkelijker carrièreperspectief voor leraren. Dit zou zowel de kwaliteit als kwantiteit van Nederlandse leraren kunnen bevorderen. Het is om die reden nuttig te verkennen op welke manieren een dergelijke versterking vorm zou kunnen krijgen. Daarvoor kan een blik over de grens in landen en onderwijsstelsels waar die versterking reeds beleid is, behulpzaam zijn, zoals in het volgende hoofdstuk wordt beschreven. 


\section{Doelstelling van het onderzoek:}

\section{leren van de loopbaanladder van leraren in Singapore}

\section{Singapore als inspirerend voorbeeld}

Singapore staat bekend als één van de best presterende landen op het gebied van onderwijs (OECD, 2012). De hoge kwaliteit van Singaporese leraren wordt gezien als één van de belangrijkste aanjagers van dit succes (Goodwin, 2014). Deze gaat gepaard met een relatief hoge maatschappelijke waardering voor het lerarenberoep in Singapore (TALIS, 2014). De kwaliteit van het Singaporese lerarencorps leunt op drie pijlers: (1) het rekruteren van talentvolle studenten voor de lerarenopleiding; (2) een lerarenopleiding van hoge kwaliteit; en (3) duurzame professionele ontwikkeling van leraren (Goodwin, 2014). Dit laatste, duurzame professionele ontwikkeling van leraren, wordt gestimuleerd door leraren de mogelijkheid te bieden om gedurende hun loopbaan door te groeien naar hogere posities en loonschalen via een van drie aan elkaar verwante tracks (routes): een Teaching Track, een Leadership Track en een Senior Specialist Track (voor een uitgebreide beschrijving: zie hoofdstuk 5). Elke route kent verschillende, oplopende, posities met bijbehorende salariëring. Wie een stapje omhoog, naar links, of naar rechts wil zetten op de loopbaanladder, kan aanvullende scholing volgen en mentoring krijgen. Dit gaat meestal om relatief korte programma's van enkele weken tot maanden, waarna leraren de nieuwe kennis en vaardigheden op de eigen school toepassen. In het model zijn vormen van nascholing en de positie op de loopbaanladder daarmee explicieter aan elkaar gekoppeld dan in Nederland.

\section{Link met Nederlandse beleidswensen}

Een aantrekkelijk aspect van het Singaporese model is dat de loopbaanladder van leraren zowel versterkt wordt in verticale zin, met verschillende opeenvolgende posities, als in horizontale zin, met verschillende specialisatiemogelijkheden voor leraren. De verticale versterking is in lijn met een wens die in Nederland ook is geformuleerd (Evers, 2007; Gerrichhauzen, 2007) om een junior-medior-senior-systeem te hanteren bij een verdere functiedifferentiatie voor leraren. De horizontale versterking is in lijn met de wens om leraren ruimte te bieden om het lesgeven te combineren met andere taken, en dergelijke specialisatiemogelijkheden ook te vertalen in een verdere functiedifferentiatie voor leraren (Commissie Leraren, 2007). Een interessante vraag is of deze horizontale en verticale versterking tevens een impuls biedt aan participatie in professionele ontwikkelingsactiviteiten door leraren.

\section{Dit onderzoek}

In dit onderzoek bekijken we of het Singaporese model, of aspecten daarvan, als voorbeeld zouden kunnen dienen bij het versterken van de professionele ontwikkeling en carrièreperspectieven van leraren in Nederland. Daartoe wordt allereerst het model, en met name de werking van het model in de praktijk, verkend. Vervolgens wordt aan de hand van enkele beleidsdoelstellingen uit de Lerarenagenda 2013-2020 zowel de zogeheten rationaliteit van het model, dat wil zeggen de mate waarin het 'beleidsmiddel' past bij de 'beleidsdoeleinden', als de legitimiteit, dat wil zeggen de mate waarin het model wenselijk of aanvaardbaar zou zijn voor verschillende stakeholders, verkend.

Het versterken van de loopbaanperspectieven van leraren en het versterken van de professionele ontwikkeling van leraren zijn twee verschillende doelstellingen, die evenwel in meerdere opzichten met elkaar verbonden lijken. Vanuit beide perspectieven is al eerder naar het Singaporese model verwezen als mogelijk inspirerend voorbeeld (Cörvers, 2014; CPB, 2014). Ook de Singaporese overheid koppelt beide doelstellingen expliciet aan elkaar (zie onder meer: Teo, 2001). In dit onderzoek wordt het Singaporese model dan ook verkend vanuit het oogpunt van beide doelstellingen, waarbij expliciet ook de relatie tussen beide wordt onderzocht. 


\section{Opzet van het onderzoek}

\section{Doel}

Het doel van dit onderzoeksproject is tweeledig. Allereerst beoogt het de loopbaanladder en post-initiële professionele ontwikkeling van leraren in Singapore in kaart te brengen. Ten tweede wil het onderzoek verkennen in hoeverre kenmerken van het Singaporese model tegemoet zouden kunnen komen aan enkele beleidsdoelstellingen uit de Nederlandse Lerarenagenda 2013-2020.

\section{Opzet}

Ten behoeve van de eerste doelstelling is gericht informatie verzameld over theorie en praktijk van het loopbaan- en professionaliseringsmodel van Singaporese leraren. Aan de hand van beleidsdocumenten en gesprekken met betrokkenen is getracht meer zicht te krijgen op de opzet van het model en op de werking van het model in de praktijk. Hiertoe zijn verschillende betrokkenen uit beleid, wetenschap en de praktijk in Singapore bevraagd over hun ervaringen met het model.

Ten behoeve van de tweede doelstelling is een analyse gemaakt van de rationaliteit en legitimiteit van het Singaporese model, aan de hand van drie beleidsdoelstellingen uit de Lerarenagenda 2013-2020:

- blijvende bekwaamheid, door leraren te stimuleren continu te werken aan professionele ontwikkeling

- horizontale versterking van de loopbaanmogelijkheden voor leraren, door verbreding van de expertise en inzetbaarheid van leraren

- verticale versterking van de carrièreperspectieven van aankomende en huidige leraren aan de hand van verbeterde doorgroeimogelijkheden

De rationaliteit en legitimiteit van het Singaporese model in het licht van bovenstaande beleidsdoelstellingen zijn verkend in dialoog met verschillende experts uit onderzoek, beleid en praktijk in Nederland. Hen is gevraagd vanuit hun eigen kennis en ervaring te reflecteren op de meer en minder geschikte en aantrekkelijke kanten van het Singaporese model vanuit Nederlands perspectief, en de vraag wat Nederland van het model zou kunnen leren.

\section{Gesprekspartners}

In bijlage 1 en 2 staan de gesprekspartners in Singapore en Nederland vermeld. Uitgangspunt voor de gesprekken met vertegenwoordigers van het Singaporese en Nederlandse onderwijsveld was een verkenning vanuit het perspectief van beleidsmakers, onderzoekers, opleiders, schoolleiders en leraren. Door de opzet van het Singaporese model overlappen deze rollen in de Singaporese context regelmatig (zie hoofdstuk 5). Zo zijn schoolleiders en veel beleidsmedewerkers voormalige leraren die de Leadership Track doorlopen. Deze werknemers kunnen dus niet alleen reflecteren op het model als middel voor de professionalisering van leraren vanuit hun huidige functie, maar ook op hun eigen ervaringen met het model als hulpmiddel om zelf van beginnende leraar op te klimmen tot hun huidige positie.

Bij de uitvoering van het veldwerk in Singapore kwam aan het licht dat Singaporese scholen sinds enkele jaren werken met zogeheten school staff developers (SSD's), die vanuit de schoolleiding verantwoordelijk zijn voor de professionele ontwikkeling en loopbaanbegeleiding van docenten. Aangezien deze functionarissen de spil zijn in de uitvoering van het loopbaan- en professionaliseringsmodel, is besloten om in plaats van drie schoolleiders, één schoolleider en twee SSD's te interviewen. Een andere wijziging ten aanzien van de oorspronkelijke opzet is dat er geen leraren zijn geïnterviewd die de Senior Specialist Track volgen. Deze track bleek slechts door zeer weinig leraren te worden gevolgd (zie hoofdstuk 5). Naar de redenen hiervoor is uiteraard gevraagd in de gesprekken met leraren en beleidsmakers, en deze komen in deze rapportage ook aan bod. Met medewerkers van het National Institute of Education vonden de interviews 
noodgedwongen per e-mail plaats: zij verkeerden ofwel voor onderzoek in het buitenland, of hielden een langere sabbatical.

\section{Veldwerk in Singapore}

Afspraken voor interviews zijn in eerste instantie tot stand gekomen via het Ministry of Education, in het bijzonder de Academy of Singapore Teachers. Langs deze weg konden interviews gepland worden met beleidsverantwoordelijken, docenten en SSD's. Daarnaast is via het eigen academische netwerk contact gelegd met onderzoekers, en van daaruit weer met trainers, van het National Institute of Education en met een schoolleider. Voor het onderzoek zijn scholen voor primair en voortgezet onderwijs bezocht, waaronder zowel een VO-school die een equivalent van het vmbo aanbiedt ('normal') als een VO-school die meer algemeen vormende tracks aanbiedt.

Informanten ontvingen een flyer met informatie over de achtergrond en doelstellingen van het onderzoek. Zowel in de flyer als voorafgaand aan de gesprekken is benadrukt dat respondenten zijn benaderd om informatie en ervaringen te delen, om zo een beter beeld te krijgen van het Singaporese model. Hen is verzekerd dat er geen citaten in het rapport gebruikt zouden worden, noch dat de informatie die in het rapport wordt gepresenteerd direct zou zijn terug te voeren tot individuele informanten. Respondenten kregen de keuze of het interview digitaal werd opgenomen of op papier werd bijgehouden.

Ten behoeve van het veldwerk is een interview-leidraad opgesteld, die is voorgelegd aan het Ministerie van $\mathrm{OCW}$ en de Kritische Vrienden van de Lerarenagenda, waarna nog enkele bijstellingen en aanvullingen zijn gedaan. Aan de hand van deze interview-leidraad zijn gestructureerde interviews afgenomen. Respondenten kregen specifieke vragen voorgelegd over hun ervaringen met het model, die waren toegespitst op hun functie. Daarnaast werden zij uitgenodigd vrij te reflecteren op hun ervaringen met het model.

\section{Analyse en verslaglegging}

De informatie uit de interviews en beleidsdocumenten is gestructureerd en verwerkt volgens de indeling die in hoofdstuk 5 en 6 zijn aangehouden. Op basis van deze informatie is een eerste theoretische verkenning uitgevoerd naar de vraag in hoeverre aspecten van het Singaporese model zouden kunnen bijdragen aan de drie genoemde beleidsdoelstellingen uit de Lerarenagenda. De bevindingen zijn in een tussenrapportage mondeling en schriftelijk gepresenteerd aan een groep Nederlandse betrokkenen uit het onderwijsveld (zie bijlage 2). In deze bijeenkomst is eerst in drie groepsrondes, ingedeeld naar de drie beleidsdoelstellingen, en vervolgens in een plenaire dialoog verkend in hoeverre de loopbaanladder van leraren in Singapore als model zou kunnen bijdragen aan de drie genoemde beleidsdoelstellingen, welke elementen aantrekkelijk en geschikt lijken voor de Nederlandse context en voor welke stakeholders het model met name aantrekkelijk, of juist minder aantrekkelijk, zou kunnen zijn. De opbrengsten van deze dialoog zijn verwerkt in het slothoofdstuk van dit rapport. 


\section{Vooraf: enkele kenmerken van het Singaporese onderwijs}

Het is van belang het onderzochte model te plaatsen tegen de bredere achtergrond van het Singaporese onderwijsstelsel. Het voert uiteraard te ver om in dit rapport uitgebreid stil te staan bij alle ins en outs van het Singaporese onderwijsstelsel. Hieronder worden enkele grote lijnen en enkele in het oog springende kenmerken van het Singaporese onderwijs besproken, die mogelijk danwel evident van invloed zijn op de manier waarop de loopbaanladder van leraren in Singapore functioneert.

\section{De organisatie van het scholenveld in Singapore}

Het Singaporese onderwijs is een op Angelsaksisch model geënt stelsel van scholen voor primair en secundair onderwijs. Het secundair onderwijs kent, net als in Nederland, verschillende tracks, van een equivalent van het Nederlandse vmbo tot algemeen vormend onderwijs dat voorbereidt op de universiteit. Er zijn in totaal 370 scholen voor primair en voortgezet onderwijs, die georganiseerd zijn in 30 clusters. Scholen binnen een cluster werken intensief met elkaar samen in onderwijsontwikkeling en -verbetering. $\mathrm{Er}$ is geen Inspectie van Onderwijs: scholen monitoren en benchmarken de onderwijskwaliteit binnen het eigen cluster, onder leiding van een Cluster Superintendent. De clusters zijn weer verdeeld over 4 zones. In totaal werken er tussen de 33.000 en 34.000 education officers in Singapore. Hieronder vallen zowel leraren als voormalige leraren die via één van de tracks naar een leiderschaps- of specialisten-rol zijn opgeklommen. Er bestaan geen grote verschillen in de organisatie van PO- en VO-scholen. Dit onderscheid komt daardoor ook weinig aan bod in het rapport. Post-secundaire onderwijsinstellingen, zoals ITE's (equivalent van Nederlands MBO), polytechnics (HBO) en universiteiten vallen niet onder de verantwoordelijkheid van het Ministerie van Onderwijs en maken ook geen gebruik van het loopbaanmodel voor leraren. Deze sectoren vallen daarmee buiten het bestek van dit rapport.

\section{Scholen en leraren vallen direct onder het Ministerie van Onderwijs}

PO- en VO-scholen ressorteren, op enkele uitzonderingen na, volledig onder het Ministerie van Onderwijs. Medewerkers op deze scholen zijn rechtstreeks in dienst van het Ministerie van Onderwijs. Voor leraren begint dit dienstverband zelfs al tijdens hun opleiding. Dit heeft belangrijke consequenties voor de mobiliteit van leraren tussen scholen, die in Singapore groot is, en de zeggenschap van het Ministerie over de plaatsing van onderwijspersoneel. Het Ministerie speelt een belangrijke rol in het aansturen van de werving van leraren op bepaalde functieniveaus. Het onderwijsstelsel wordt als één geheel gezien, waarvoor het lerarencorps in de volle breedte inzetbaar is. Als de ene school een sterke schoolleider nodig heeft en een andere school heeft een leraar in dienst met sterke leiderschapspotenties, dan is het heel gebruikelijk dat deze leraar een overstap maakt. Op verschillende punten in dit rapport zal op deze praktijk worden teruggekomen.

\section{Korte lijnen tussen Ministerie en scholenveld}

Doordat leraren rechtstreeks in dienst zijn van het Ministerie komt het veel voor dat leraren tijdelijk een kortere of langere periode op het departement werken, niet zelden aan het begin van hun loopbaan. Andersom zie je dat leraren die opklimmen langs de Leadership Track uiteindelijk doorstromen naar functies op departementaal niveau. Hierdoor zijn de lijnen tussen het Ministerie en de onderwijspraktijk kort, en er bestaat veel begrip voor wederzijdse praktijken en perspectieven. Het wederzijds vertrouwen en de samenwerking tussen Ministerie en het scholenveld is daardoor sterk ontwikkeld.

\section{Selectie en opleiding van leraren}

De lerarenopleiding in Singapore kent een strenge selectie aan de poort: slechts 1 op de 8 kandidaten wordt toegelaten. Gedurende de lerarenopleiding geldt bovendien een bindend studie-advies. Deze selectie draagt bij aan de status van het beroep van leraar. Toch klagen ook Singaporese leraren wel over een 
tekort aan erkenning en respect voor hun vak vanuit ouders en de samenleving. Wie de volledige lerarenopleiding doorloopt, heeft een bachelor-diploma. De lerarenopleiding in Singapore is een betaalde opleiding: studenten komen direct in dienst van het Ministerie van Onderwijs en krijgen een bescheiden salaris uitbetaald: $60 \%$ van wat een beginnende leraar na het afronden van de opleiding verdient. Studenten betalen geen collegegeld. Dit maakt het ook voor zij-instromers aantrekkelijk om alsnog het onderwijs in te stromen en een bevoegdheid te halen. Alle leraren in Singapore leggen aan het eind van hun opleiding een eed af.

\section{Prestatiebeoordeling en prestatiebonus}

Leraren in Singapore worden jaarlijks op een groot aantal indicatoren beoordeeld en per school gerankt aan de hand van het Education Performance Management System. Voor elke functie bestaan verschillende prestatie-indicatoren waarop een leraar beoordeeld wordt. Het salaris van een leraar wordt voor een deel bepaald door deze beoordeling. Wie een hoge ranking behaalt, kan tot 30\% extra bovenop zijn of haar standaardsalaris verdienen. Leraren in functies hogerop de loopbaanladder, die vaak schooloverstijgend werken, worden gerankt binnen hun eigen functiegroep op het niveau van het Ministerie. Het lerarensalaris in Singapore is niet bijzonder hoog, maar kan door de bonussen wel aantrekkelijker worden gemaakt.

\section{Cultuur en bestuur}

Er bestaat in Singapore vanuit een confucianistische traditie een grote nadruk op hard studeren en werken. Daardoor bestaat weleens de indruk dat Singaporese werknemers zonder morren een enorme werklast dragen en niet snel in het geweer zullen komen als hun baas veel van ze eist. In dat licht is het goed te vermelden dat Singaporese leraren een hoge werkdruk ervaren, en dat die als belangrijkste verklaring wordt gegeven voor het jaarlijks percentage, rond de 3\%, van de leraren dat het leraarschap vaarwel zegt. Singapore wordt in vergelijking met Nederland centralistischer aangestuurd. De rol van het Ministerie in het onderwijsveld is in veel opzichten sturender dan in Nederland, zoals op verschillende punten in dit rapport aan de orde komt. Toch heeft Singapore juist op dit punt de afgelopen jaren een opvallende omslag gemaakt. Waar voorheen meer top down gepland werd, wordt nu expliciet ruimte gecreëerd voor scholen en leraren om onderlinge afspraken en eigen keuzes te maken. Deze omslag werd door verschillende betrokkenen in dit onderzoek genoemd. De Singaporese overheid legt in toenemende mate nadruk op initiatief, creativiteit en eigenaarschap als essentiële ingrediënten van een moderne kenniseconomie en, dus, van het onderwijs. 


\section{De Singaporese loopbaanladder van leraren}

Eind jaren '90 van de vorige eeuw heeft Singapore het gehele onderwijsstelsel in al zijn facetten grondig doorgelicht, om vast te stellen op welke vlakken het stelsel verder ontwikkeld en verbeterd kon en moest worden. Een van de resultaten van deze evaluatie was de lancering van Edu-Pac in 2001, het Education Service Professional Development and Career Plan voor leraren. In dit plan werden drie loopbaanpaden gepresenteerd waarlangs leraren zich kunnen ontwikkelen. Het Ministerie sprak de verwachting uit dat deze drie tracks leraren zouden motiveren in, en ondersteunen bij, het streven naar excellentie (zie: Liew, 2012). Toenmalig Minister van Onderwijs Teo Chee Hean lichtte toe dat met Edu-Pac de professionele ontwikkeling van leraren directer wordt verbonden aan de loopbaanladder van leraren en aan de erkenning van de verantwoordelijkheden en prestaties van leraren (Teo, 2001). In dit hoofdstuk wordt deze loopbaanladder nader beschreven. In het daaropvolgende hoofdstuk wordt nader ingegaan op de professionalisering van leraren in Singapore.

\section{DE DRIE TRACKS}

De Singaporese loopbaanladder van leraren kent drie tracks, die in figuur 1 hieronder staan afgebeeld. De functieniveaus van de drie tracks die met elkaar op één horizontale lijn staan, corresponderen met elkaar in status en salariëring. Zo staat de functie van master teacher uit de Teaching Track op gelijke voet met die van vice principal in de Leadership Track. Behalve verticale bestijging van opeenvolgende treden binnen een van de drie tracks, is horizontaal overstappen ook mogelijk. Zo komt een overstap van vice principal naar master teacher bijvoorbeeld met enige regelmaat voor. Elke trede in het model kent een nadere differentiatie in drie functieschalen. Er geldt een beloningsplafond voor elke functie. Dat betekent dat het salaris van een leraar die niet verder opklimt langs de ladder na verloop van tijd niet verder kan groeien, met uitzondering van het gedeelte dat bepaald wordt door de prestatiebonus.

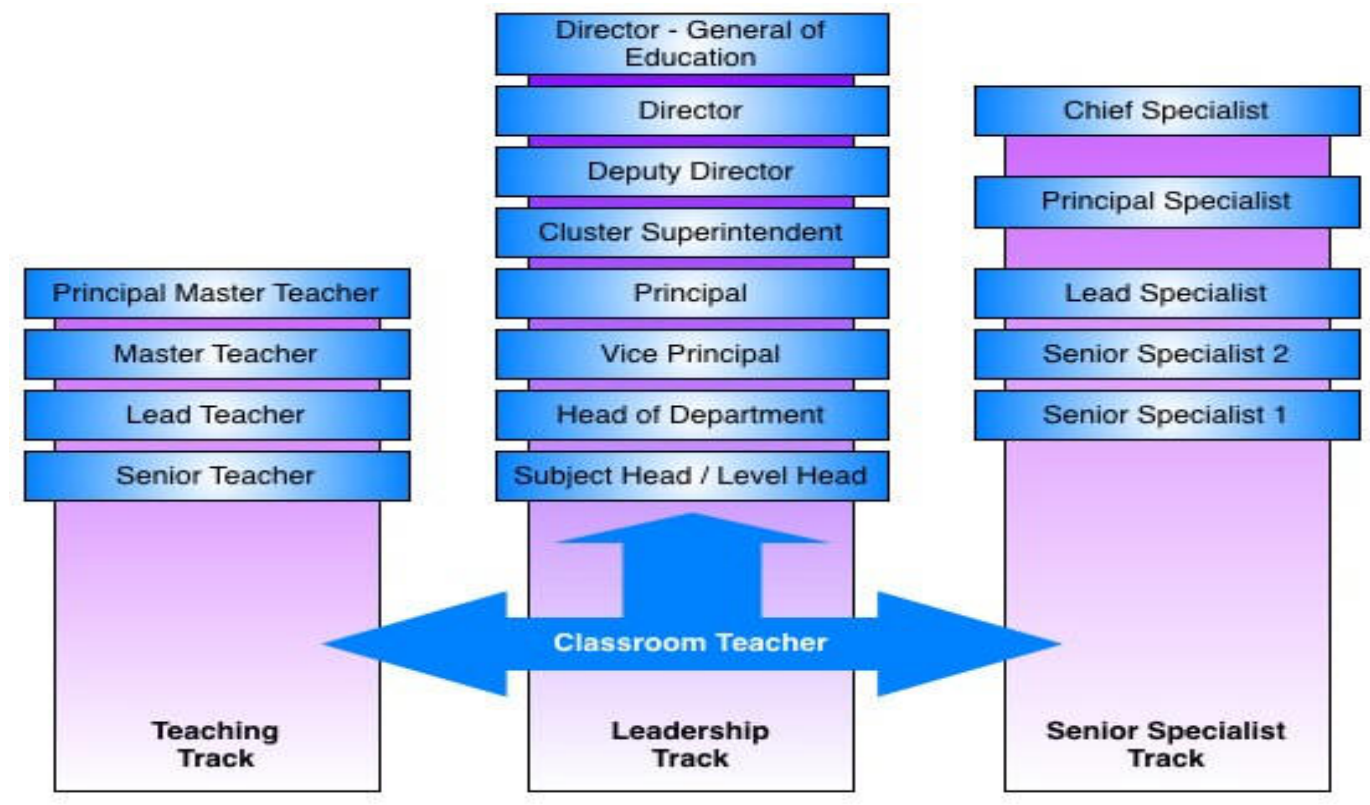

Figuur 1: de drie tracks

(Afbeelding afkomstig van: https:/ / tomnewpalt:wordpress.com/2014/04/05/singapore-teacher-tracks)

\section{De basis: de classroom teacher}

$\mathrm{Na}$ de lerarenopleiding starten alle leraren als reguliere classroom teacher. Zij geven de eerste drie jaar 20\% minder les dan hun meer ervaren collega's. Daarnaast krijgen beginnende leraren uitgebreide mentoring op 
de school waar zij starten. Zij krijgen in hun eerste jaren de ruimte om aan de hand van verschillende cursussen, korte meeloopstages en gesprekken te verkennen welke track het beste bij ze zou passen. Na drie jaar gaat een leraar 'de markt op', om een positie te vinden in één van de scholen. Het vinden van een baan na de driejarige inductieperiode vindt zowel plaats binnen de eigen school, binnen het cluster waar de school deel van uitmaakt als via een portal van het Ministerie waar beschikbare plekken worden aangeboden. De leraar zorgt ervoor dat hij of zij een geschikt portfolio heeft opgebouwd, desgewenst met vaardigheden die passen bij de beoogde track. Veel leraren die verwachten de Leadership Track te volgen, lopen in hun eerste jaren bijvoorbeeld een tijdje stage bij het Ministerie van Onderwijs, waar leraren die neigen naar de Teaching Track vaak een tijdje rondlopen bij de Academy of Singapore Teachers, een zelfstandig onderdeel van het Ministerie van Onderwijs. Beslist niet alle leraren stromen na de eerste drie jaar direct door naar een van de tracks. Leraren kunnen ook voor langere tijd een 'gewone' classroom teacher blijven, een zogeheten general education officer, bijvoorbeeld omdat ze nog niet toe zijn aan een verzwaring van hun verantwoordelijkheden of verbreding van hun takenpakket, of omdat ze eerst nog een Master willen doen voordat ze zich willen aanbieden voor een hogere functie. Veel leraren blijven langere tijd general education officer, alhoewel men ervaart dat jonge leraren tegenwoordig gerichter bezig zijn met hun loopbaanontwikkeling en sneller promotie willen maken. Leraren die geen verdere promotie maken, hebben na zes jaar te maken met een salarisplafond.

\section{DE TEACHING TRACK}

\section{Treden}

De Teaching Track is bestemd voor leraren die zich in hun loopbaan willen blijven concentreren op het lesgeven zelf en op de ontwikkeling van het didactisch repertoire van leraren. Oorspronkelijk kende de Teaching Track slechts twee treden: senior teacher en master teacher. Om de Teaching Track aantrekkelijker te maken, en om tegemoet te komen aan de wens van leraren om zich te kunnen blijven ontwikkelen zonder het lesgeven vaarwel te hoeven zeggen, zijn de functies van lead teacher en principal master teacher in 2009 ingevoerd. Tegelijkertijd is de functie van master teacher opgeschaald en gelijkgeschakeld an het niveau van vice principal in de Leadership Track. Sinds deze opschaling komt het vaker voor dat vice principals uit de Leadership Track de overstap maken naar de functie van master teacher in de Teaching Track. Deze overstappers kiezen ervoor om zich niet verder te specialiseren in het schoolleiderschap, maar zich weer meer te richten op het primaire onderwijsproces.

In 2014 telde Singapore 1700 senior teachers, 100 lead teachers, 51 master teachers en 5 principal master teachers. De Teaching Track heeft daarmee een duidelijke piramidestructuur. Het aantal lead teachers en principal master teachers is mede beperkt doordat dit relatief nieuwe functies zijn. De Singaporese overheid zet momenteel actief in op het vergroten van het aantal senior en lead teachers in de scholen. Senior teachers zijn leraren die hun kennis en vaardigheden hebben verdiept en verbreed en deze met name inzetten voor de ontwikkeling en verbetering van het onderwijs op de eigen school. Lead teachers nemen daar bovenop ook een voortrekkersrol in de ontwikkeling en verbetering van het onderwijs op cluster-niveau. Master teachers en principal master teacher werken niet op één school, maar zetten hun kennis en vaardigheden in vanuit de Academy of Singapore Teachers, waar gewerkt wordt aan de professionele ontwikkeling van leraren op landelijk niveau. Figuur 2 op de volgende pagina illustreert deze opbouw.

\section{Status}

In de ervaring van leraren heeft de Teaching Track van oudsher iets minder status dan de Leadership Track. Men verwacht echter dat dit zal veranderen, dankzij de introductie van de nieuwe treden van lead teacher en principal master teacher, en dankzij het actieve beleid van de overheid om meer senior en lead teachers aan te stellen. Daarnaast geven leraren aan dat de overstap naar senior teacher voorheen wat te pittig was, doordat leraren een zeer uitgebreid portfolio dienden op te bouwen alvorens in aanmerking te komen voor deze 
functie. Instromen in de Leadership Track vergde op dit punt minder. Bovendien vonden veel leraren dat de functie van senior teacher zwaar en onduidelijk afgebakend was. Hierdoor was de functie van head of department in de Leadership Track een aantrekkelijker positie voor wie inhoudelijk sturing wil geven aan een lerarenteam. Het Ministerie heeft inmiddels de functie-omschrijving en eisen voor senior teacher herzien om de instroom op dit niveau te vergroten. De nadruk ligt nu nog sterker op pedagogisch leiderschap.

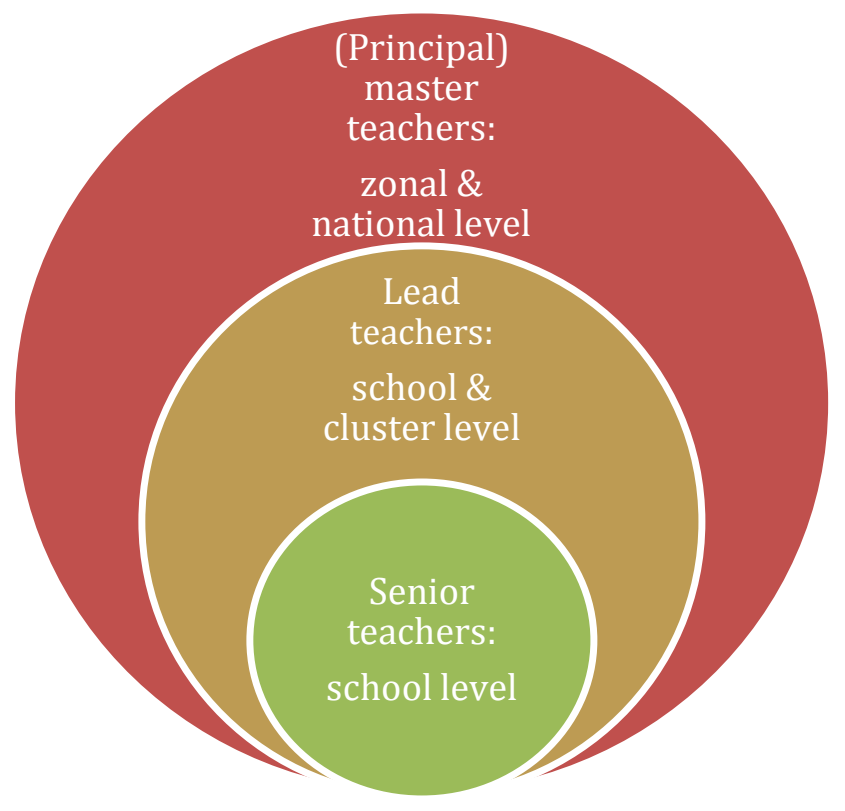

Figuur 2: rol en reikwijdte functies Teaching Track

\section{DE LEADERSHIP TRACK}

\section{Treden}

De Leadership Track kent een groot antal treden die oplopen tot de hoogste beleidsfunctie op departementaal niveau, de functie van Directeur-Generaal. Alle scholen hebben meerdere subject beads (voortgezet onderwijs) of level heads (primair onderwijs) in dienst, die een vaksectie of leerjaar aansturen. Elke school kent bovendien meerdere heads of department, die je zou kunnen vergelijken met bouwcoördinatoren of deelschoolleiders. Daarnaast heeft elke school standaard twee vice principals (in totaal 740 voor heel Singapore) en één principal (in totaal 370 voor heel Singapore). De functies boven het niveau van principal zijn buitenschoolse functies op cluster- of departementaal niveau. Elke cluster heeft één superintendent (in totaal 30 voor heel Singapore).

\section{Status}

De Leadership Track is de meest gebruikte track van de Singaporese loopbaanladder van leraren, onder meer door de structurele vraag naar sectiehoofden en schoolleiders. Deze track heeft in de beleving van leraren iets meer status dan de Teaching Track, al zal dat naar verwachting veranderen (zie hierboven). Aan de populariteit draagt bij dat leraren met leiderschapspotentie vaak al vroeg in hun loopbaan worden geïdentificeerd en vervolgens versneld de Leadership Track kunnen instromen. 


\section{DE SENIOR SPECIALIST TRACK}

\section{Treden}

De Senior Specialist Track is in meerdere opzichten afwijkend van de andere twee tracks. De senior specialisten werken niet op de scholen zelf maar op het Ministerie, bij de divisies Curriculum Planning \& Development en Student Development Curriculum. Daarnaast is de track alleen toegankelijk voor leraren die een Master-diploma hebben (voor de functie van senior specialist) of een $\mathrm{PhD}$ (voor de functies van lead specialist en hoger). Er zijn maar weinig leraren die deze track volgen. In 2012 was er sprake van 181 senior specialists, 3 lead specialists en 4 principal specialists. De specialisten werken in vier domeinen: curriculum \& instructional design, educational psychology \& guidance, educational testing \& measurement en educational research \& statistics. Senior specialisten vormen vaak een brug tussen onderwijsonderzoek en de onderwijspraktijk. Om die reden wordt het van belang gevonden dat zij zelf ook praktijkervaring hebben als leraar. Wie senior specialist wil worden, werkt meestal meerdere jaren op het Ministerie van Onderwijs, bijvoorbeeld bij de divisie Curriculum Planning \& Development, alvorens aan deze track te beginnen.

\section{Status}

De specialisten werken tamelijk geïsoleerd. Zo is er in heel Singapore bijvoorbeeld maar één senior specialist voor het vak scheikunde. De specialisten zijn daardoor minder zichtbaar, wat maakt dat leraren niet zo snel in aanraking komen met hun werk. Bij de keuze voor een track maken de meeste leraren hierdoor feitelijk een afweging tussen de Teaching Track en de Leadership Track. Daar komt bij dat veel leraren die net van de lerarenopleiding komen het zonde van hun opleiding vinden om fulltime als ambtenaar bij het Ministerie te gaan werken. De functie-omschrijving van de specialisten sluit minder aan bij de motivatie om leraar te worden. Het Ministerie van Onderwijs zet momenteel actief in op het vergroten van het aantal senior specialists.

\section{INSTROMEN EN OPSTROMEN}

\section{Instromen in één van de drie tracks}

Leraren kiezen zelf in welke track zij instromen, maar er vindt ook een zekere sturing plaats vanuit de overheid. Zo worden er de laatste jaren meer senior teachers aangezocht, wat betekent dat leraren actief worden gestimuleerd om de overstap naar de Teaching Track te maken. Er is soms sprake van actieve grooming: het vroegtijdig identificeren van leraren met bepaalde talenten, die vervolgens actief worden gestimuleerd om zich in een gewenste richting te ontwikkelen. Er lijkt met name enige druk te bestaan op talentvolle leraren om voor de Leadership Track te kiezen, vanwege de structurele behoefte an schoolleiders. Leraren maken de keuze echter uiteindelijk zelf. Hoewel de meeste beginnende leraren de reguliere driejarige verkenningsperiode doorlopen alvorens een keuze voor een track te maken, worden sommige jonge docenten met leiderschapspotentie al eerder geïdentificeerd en versneld klaargestoomd voor de Leadership Track. Zij gaan kort na het afronden van hun initiële opleiding twee jaar op het Ministerie van Onderwijs werken en stromen vervolgens versneld de Leadership Track in.

\section{Zij-instroom}

De meeste zij-instromers zijn werknemers die alsnog een volledige lerarenopleiding volgen, of vakspecialisten die alsnog hun lesbevoegdheid halen. Zij doorlopen vervolgens eenzelfde route als leraren die niet eerst een andere loopbaan hebben gevolgd. Het feit dat leraren in de voltijdse lerarenopleiding direct in dienst komen van het Ministerie en salaris ontvangen, vergemakkelijkt een latere overstap naar het onderwijs. In de Leadership Track wordt ook direct 'van buitenaf' ingestroomd. Zo kennen scholen vice principals 'academic', die leraar zijn geweest en zich meer met de onderwijsinhoudelijke kant bezighouden, en vice principals 'administration', die meestal geen leraar zijn geweest en die zich meer op de zakelijke kant van 
het schoolmanagement richten. In deze laatste positie stromen relatief veel ambtenaren vanuit het Ministerie van Onderwijs in. De meeste ambtenaren op het Ministerie zijn geen (voormalige) leraren.

\section{Promotie maken}

Leraren die promotie willen maken, bespreken dit met hun reporting officer en de school staff developer (zie hoofdstuk 6). Aangezien gesprekken tussen leraren, hun reporting officer en school staff developers in de regel meerdere keren per jaar plaatsvinden, zal over het algemeen geleidelijk toegewerkt worden naar een hogere functie. In overleg wordt bekeken of de leraar geschikt zou zijn voor een bepaalde functie, of hij al klaar is om door te groeien, en of hij ter voorbereiding nog bepaalde vaardigheden zou moeten ontwikkelen of bijspijkeren. Bij het jaarlijks plannen van professionele ontwikkelingsactiviteiten wordt desgewenst rekening gehouden met eventuele loopbaanwensen voor de nabije toekomst (zie ook hoofdstuk 6), zodat de leraar een portfolio kan opbouwen dat hem of haar zoveel mogelijk geschikt maakt voor de gewenste functie. Met uitzondering van de vereiste master- of PhD-graad voor senior specialists, is er echter geen sprake van nascholing als ingangseis voor een bepaalde functie. Nascholingsprogramma's die specifiek gericht zijn op bepaalde functies (de zogeheten milestone programmes, zie hoofdstuk 6) worden in de regel ná de benoeming aangeboden, en niet ervoor. Meestal krijgt een leraar de kans een nieuwe rol eerst uit te proberen, door mee te lopen met een collega en/of een bepaalde training te volgen die de leraar nader kennis laat maken met de taken en verantwoordelijkheden die horen bij de beoogde functie. Wanneer een leraar promoveert naar een nieuwe functie, wordt hij of zij direct ondergedompeld in de nieuwe rol, met ondersteuning van een mentor en een trainingsprogramma. Het voltooien van een bepaalde vorm van nascholing geeft geen recht op een bepaalde positie. De gedachte hierachter is dat elke leraar de kans krijgt om promotie te maken naar een hogere functie, en niet alleen de leraren die geselecteerd zijn voor bepaalde trainingsprogramma's voor high potentials, zoals het Leaders in Education Programme (zie hoofdstuk 6). Ook wil men hiermee voorkomen dat professionele ontwikkeling wordt gezien als een vehikel om snel promotie te maken (extrinsieke motivatie) in plaats van als middel om jezelf te ontwikkelen tot een betere leraar (intrinsieke motivatie).

De kans op promotie hangt af van de potentie, prestatie, kennis en ervaringen van een leraar en van de beschikbaarheid van plaatsen. Het Education Performance Management System (zie hoofdstuk 4) speelt hierin een belangrijke rol. Een leraar kan 'genomineerd' worden voor promotie door een leidinggevende, waarna het portfolio en evaluaties van de leraar worden bekeken en er een selectiegesprek plaatsvindt. In het portfolio kan een leraar een persoonlijke toelichting geven op zijn ambities en ervaringen en deze onderbouwen met voorbeelden, materialen en gegevens uit zijn lespraktijk.

\section{Mobiliteit tussen scholen}

Leraren kunnen promotie maken binnen hun school, maar in veel gevallen betekent promotie een overstap naar een andere school. Er is sprake van een hoge mate van mobiliteit tussen scholen. De meeste leraren werken gedurende hun loopbaan op verschillende scholen. Dit wordt door alle betrokkenen positief ervaren. Men ervaart dat leraren 'van buiten' nieuwe kennis en ideeën de school inbrengen, en het gevoel overheerst dat wie te lang op één school werkt, eventuele problemen onvoldoende signaleert. Mobiliteit wordt actief gestimuleerd. Zo is het gebruikelijk dat een principal maximaal 6 jaar op één plek blijft zitten en daarna ofwel opklimt ofwel naar een andere school gaat.

Een leraar kan via het open posting-systeem van het Ministerie naar een nieuwe functie zoeken. Vaak ook vindt een overstap naar een andere school plaats binnen het cluster waartoe de school behoort. Schoolleiders, head of departments en school staff developers hebben regelmatig contact met hun collega's binnen hetzelfde cluster. Zij bekijken onderling of er posities beschikbaar zijn voor een leraar die een stapje hogerop wil. Anderzijds maken scholen op cluster-niveau onderling ook wel afspraken om talenten niet voor elkaars neus weg te kapen.

Het actieve grooming-beleid vanuit het Ministerie wordt door sommige scholen als storend ervaren. Wanneer een jonge leraar een duidelijke high potential is, betrappen scholen zich weleens op de neiging 
minder in de ontwikkeling van zo'n leraar te investeren, omdat high potentials al snel naar het Ministerie verdwijnen of worden geselecteerd voor het prestigieuze Leaders in Education Programme (zie hoofdstuk 6) Scholen investeren in zo'n geval liever in de begeleiding en ontwikkeling van de sub-top, van wie de kans groter is dat ze langer binnen de school of het cluster blijven.

\section{Niet opstromen}

Sommige leraren voelen weinig voor het uitbreiden van hun takenpakket of het verzwaren van hun verantwoordelijkheden. Daar is ruimte voor: er is geen sprake van een move up or move out systeem. Leraren die gezien worden als high potentials ervaren soms wel druk om snel promotie te maken. Zeker omdat promotie vaak gepaard gaat met een overstap naar een nieuwe school, zouden zij soms liever wat langer aanblijven in een bepaalde positie. Een overstap naar een nieuwe functie op een nieuwe school, betekent dat zij moeten achterlaten wat zij net zorgvuldig hebben opgebouwd. Deze leraren worden door hun reporting officers vaak overgehaald om de stap toch te maken. Dit gebeurt vanuit het idee dat de behoeften van het onderwijs en de leerlingen bepalend zijn. De education officer is een middel om het onderwijs te verbeteren en wordt ingezet daar waar hij of zij het meeste kan bijdragen. Toch geven leraren aan dat hun wil uiteindelijk bepalend is. Wie langer in een positie wil blijven, niet hogerop wil, of liever een andere track wil dan 'het systeem' vraagt, krijgt daar ruimte voor.

\section{Rol prestatiebonus}

Leraren die jaarlijks een goede ranking krijgen in hun functiegroep, en daardoor een mooie prestatiebonus ontvangen, aarzelen soms om promotie te maken. In hun nieuwe functie zullen zij in beginsel niet tot de toppresteerders behoren, waardoor zij vrezen minder bonus te krijgen. Deze negatieve prikkel wordt tegengegaan door iets lagere rankings in hogere posities in de eerste jaren gelijk te stellen aan top rankings in lagere posities bij het berekenen van de prestatiebonus. Niet alle leraren blijken echter op de hoogte van deze regeling: school staff developers zeggen leraren vaak te moeten vertellen dat de prestatiebonus geen belemmering voor opklimmen hoeft te zijn. 


\section{Professionele ontwikkeling van leraren in Singapore}

\section{POSITIONERING PROFESSIONELE ONTWIKKELING}

\section{Recht of plicht}

De Singaporese overheid wil dat de initiële opleiding van leraren en post-initiële professionalisering één continuüm vormen, waarlangs de leraar zich permanent ontwikkelt en verbetert. Leren moet deel uitmaken van het dagelijks werk van de leraar. Er moet een continue energie van vooruitgang stromen en stagnatie dient voorkomen te worden. Daartoe wordt onder meer het curriculum elke zes jaar herzien, zodat alle leraren genoodzaakt zijn zich bij te spijkeren en hun lessen aan te passen. Voorheen gold een verplichting van 100 uur professionele ontwikkeling per jaar, en het volmaken van deze 100 uur werd op veel scholen meegenomen als een prestatie-indicator voor leraren. Dit stuitte veel betrokkenen tegen de borst. Professionalisering werd door het verplichte karakter een vervelende taak, waardoor leraren vooral zochten naar manieren om redelijk makkelijk aan hun 100 uren te komen. Het discourse is veranderd door de 100 uur expliciet als een recht te positioneren, in plaats van als een plicht, en door de infrastructuur rond professionalisering sterk te verbeteren. De oprichting in 2012 van de Academy of Singapore Teachers (AST) als centrale vindplaats voor professionele ontwikkeling van leraren speelt hierin een belangrijke rol. De AST faciliteert verschillende leernetwerken, professionele leergemeenschappen en digitale platforms voor en door leraren. Professionele ontwikkeling krijgt hierdoor in de laatste jaren meer en meer de vorm van zelfsturende leergemeenschappen. De participatie in traditionele cursussen neemt daardoor de afgelopen jaren af, terwijl de tijd die aan professionele ontwikkeling wordt besteed groeit en vaak de 100 uur overstijgt.

\section{Top down of bottom up}

Met het loslaten van de 100 uren-plicht is ook afgestapt van de neiging professionele ontwikkeling gedetailleerd te willen uitstippelen en kwantificeren. Waar in het verleden meer sprake was van vastomlijnde programma's die top down werden opgelegd, geldt nu een sterk vraaggestuurd systeem, waarin leraren zelf verantwoordelijk zijn voor hun eigen professionele ontwikkeling. Dit wordt gezien als een belangrijke omslag. Professionalisering zit tegenwoordig volgens alle gesprekspartners diep in de vezels van elke leraar, van elke school en van het onderwijsstelsel als geheel. Hoewel professionaliseringsactiviteiten zeker worden geëvalueerd (zie verderop in dit hoofdstuk), probeert men de opbrengsten niet teveel te kwantificeren. Professionele ontwikkelingsuren zijn in de ogen van de meeste betrokkenen in principe nooit weggegooide uren, al erkent men dat natuurlijk niet elke scholing altijd even nuttig blijkt. Anderen hebben wel het idee dat er soms sprake is van 'overtraining' en zetten vraagtekens bij nut en noodzaak van enkele recente ontwikkelingen, zoals de participatie van elke leraar in een professionele leergemeenschap. Hoewel er is afgestapt van sterk aanbodgestuurde en top down opgelegde routes en programma's voor professionalisering, stellen alle betrokkenen in dit onderzoek dat het prettig is dat de 'hoofdroutes' enigszins zijn uitgestippeld dankzij het Teacher Growth Model (zie hieronder). Enige structuur en richtingaanwijzers zijn in hun ervaring nodig om een vraaggestuurd, bottom up model voor professionalisering te faciliteren en realiseren. Zonder zo'n structuur zouden sommige scholen en leraren teveel stilstaan, is het idee.

\section{Collectief belang}

Er heerst een breedgedragen idee dat professionalisering een noodzaak is voor alle leraren, waarvan niet alleen individuele leraren maar ook het lerarencorps als collectief beter worden. "Growing teachers as a fraternity" wordt dit genoemd. Vanuit deze collectieve gedachte, en dankzij het feit dat alle scholen onder het Ministerie van Onderwijs vallen, zijn scholen ook niet zo bang dat een leraar de opgedane kennis en 
vaardigheden van een door de school bekostigde nascholing bij de 'concurrent' zal inzetten. Als dat gebeurt, dan is het Singaporese onderwijs er als geheel immers toch beter van geworden.

\section{HET TEACHER GROWTH MODEL}

Singapore werkt aan de hand van het zogeheten Teacher Growth Model aan de post-initiële professionele ontwikkeling van leraren. Dit model onderscheidt vijf uitkomsten waar elke leraar naartoe dient te werken: de Ethical Educator, de Competent Professional, de Collaborative Learner, de Transformational Leader en de Community Builder. De dimensies staan afgebeeld in de diamant hieronder, die als verbeelding van het Teacher Growth Model wordt gehanteerd.

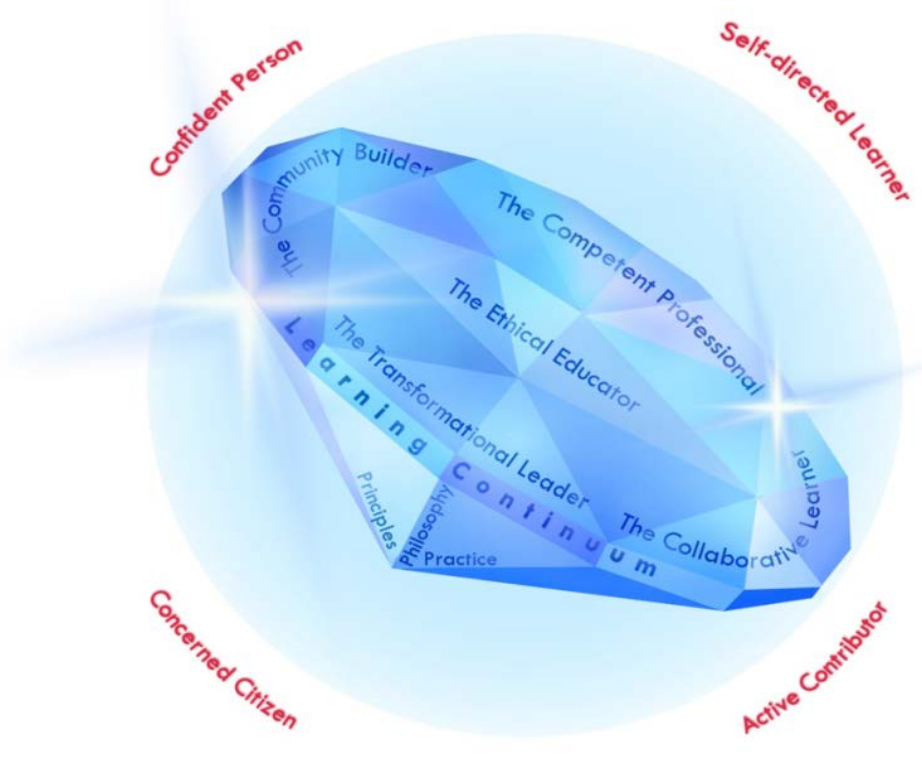

Figuur 3: het Teacher Growth Model

(Afbeelding afkomstig van: www.moe.gov.sg/media/.../fact-sheet-teacher-growth-model.pdf)

\section{Leerdomeinen}

Leraren worden geacht zich in alle vijf de domeinen te ontwikkelen. Binnen elk domein zijn een of meerdere leergebieden gedefinieerd (learning dimensions), die elk op hun beurt uiteenvallen in meerdere leerdoelen. Aan de hand hiervan kunnen leraren kiezen aan welke leerdoelen zij willen werken. Deze opzet staat weergegeven in figuur 4 op de volgende pagina.

Leraren kunnen inloggen op het online systeem TRAISI (Training Administration System on Internet). Hier kunnen zij hun eigen professionele ontwikkeling bijhouden en aldus een portfolio opbouwen. Ook kunnen zij zich via dit systeem aanmelden voor nascholingsactiviteiten en evaluaties van cursussen invoeren. In TRAISI kunnen leraren klikken op een van de vijf dimensies van het Teacher Growth Model en vervolgens een leergebied binnen die dimensie selecteren. Wanneer een leraar vervolgens klikt op één van de leerdoelen die binnen dit leergebied zijn gedefinieerd, verschijnt een overzicht van alle beschikbare cursussen die zij kunnen volgen om aan dit leerdoel te werken. Het aanbod in TRAISI omvat meer dan 1000 cursussen. 


\begin{tabular}{|c|c|c|c|c|c|c|}
\hline \multicolumn{2}{|c|}{$\begin{array}{c}\text { Teacher } \\
\text { outcome 1: } \\
\text { ethical } \\
\text { educator }\end{array}$} & \multicolumn{2}{|c|}{$\begin{array}{c}\text { Teacher } \\
\text { outcome } 2: \\
\text { competent } \\
\text { professional }\end{array}$} & \multirow{2}{*}{$\begin{array}{c}\text { Teacher } \\
\text { outcome 3: } \\
\text { collaborative } \\
\text { learner } \\
\text { Learning } \\
\text { dimension 5: } \\
\text { Learning as a } \\
\text { team }\end{array}$} & \multirow{2}{*}{$\begin{array}{c}\text { Teacher } \\
\text { outcome 4: } \\
\text { transforma- } \\
\text { tional leader } \\
\text { Learning } \\
\text { dimension 6: } \\
\text { Leading people } \\
\text { towards a shared } \\
\text { vision }\end{array}$} & \multirow{2}{*}{$\begin{array}{c}\text { Teacher } \\
\text { outcome 5: } \\
\text { community } \\
\text { builder } \\
\text { Learning } \\
\text { dimension 7: } \\
\text { Understanding } \\
\text { and engaging our } \\
\text { community }\end{array}$} \\
\hline $\begin{array}{l}\text { Learning } \\
\text { dimension 1: } \\
\text { Living out ethos } \\
\text { of the teacher } \\
\text { profession }\end{array}$ & $\begin{array}{c}\text { Learning } \\
\text { dimension 2: } \\
\text { Mastering self }\end{array}$ & $\begin{array}{c}\text { Learning } \\
\text { dimension 3: } \\
\text { Deepening } \\
\text { knowledge and } \\
\text { practice in } \\
\text { academic } \\
\text { curriculum }\end{array}$ & $\begin{array}{c}\text { Learning } \\
\text { dimension 4: } \\
\text { Deepening } \\
\text { knowledge and } \\
\text { practice in } \\
\text { student } \\
\text { development } \\
\text { curriculum }\end{array}$ & & & \\
\hline $\begin{array}{c}\text { Professional } \\
\text { ethics }\end{array}$ & Self-knowledge & Curriculum & $\begin{array}{l}\text { Learners and } \\
\text { learning }\end{array}$ & $\begin{array}{l}\text { Collaborative } \\
\text { learning }\end{array}$ & $\begin{array}{l}\text { Leader as } \\
\text { visionary }\end{array}$ & $\begin{array}{c}\text { Understanding } \\
\text { local and global } \\
\text { issues }\end{array}$ \\
\hline $\begin{array}{l}\text { Ethics in } \\
\text { subject } \\
\text { discipline }\end{array}$ & Self-efficacy & $\begin{array}{l}\text { Discipline and } \\
\text { subject content }\end{array}$ & $\begin{array}{c}\text { Student } \\
\text { development } \\
\text { curriculum }\end{array}$ & Teamwork & $\begin{array}{l}\text { Leader as } \\
\text { manager }\end{array}$ & $\begin{array}{c}\text { Engaging our } \\
\text { stakeholders }\end{array}$ \\
\hline Research ethics & $\begin{array}{c}\text { Self- } \\
\text { management }\end{array}$ & \multicolumn{2}{|c|}{ Pedagogy } & $\begin{array}{l}\text { International } \\
\text { collaboration }\end{array}$ & $\begin{array}{c}\text { Leader as people } \\
\text { developer }\end{array}$ & \\
\hline $\begin{array}{c}\text { Ethics across } \\
\text { subject } \\
\text { disciplines }\end{array}$ & & \multicolumn{2}{|c|}{ Assessment } & & $\begin{array}{c}\text { Leader as change } \\
\text { agent }\end{array}$ & \\
\hline $\begin{array}{l}\text { Ethical } \\
\text { leadership and } \\
\text { ethical culture }\end{array}$ & & \multicolumn{2}{|c|}{ Professional practice } & & & \\
\hline
\end{tabular}

Figuur 4: leerdomeinen en leerdoelen

\section{AANBOD ACTIVITEITEN}

\section{Cursussen en trainingen}

De meeste nascholing vindt traditioneel plaats in de vorm van cursussen en trainingen. Dit aanbod wordt zoveel mogelijk op de Academy of Singapore Teachers (AST) aangeboden, dat hiermee een soort campusfunctie voor leraren wil vervullen. In vrijwel alle gevallen worden cursussen op de AST verzorgd door medewerkers van het National Institute of Education (NIE), dat ook verantwoordelijk is voor de initiële opleiding van leraren. Daarnaast kopen veel scholen in-company trainingen in, met name wanneer zij menen dat alle leraren op de school deze zouden moeten volgen. Vaak worden dergelijke trainingen door andere aanbieders dan het NIE verzorgd. Zo hebben veel NIE-medewerkers zich de laatste jaren als zelfstandig trainer gevestigd. Ook biedt het Ministerie zelf professionaliseringstrajecten an op het gebied van onderwijsbeleid.

\section{Professionele leergemeenschappen}

Naast cursussen maken professionele leergemeenschappen en leernetwerken expliciet onderdeel uit van de professionele ontwikkelingstrajecten van leraren. Professionele leergemeenschappen zijn in dit geval leergemeenschappen binnen individuele scholen. Leernetwerken zijn bovenschoolse leergemeenschappen, die door de AST worden gefaciliteerd en op de campus van de AST samenkomen. Deze vorm van professionalisering wint langzaamaan terrein van de meer traditioneel opgezette cursussen en trainingen. Men spreekt in dit kader wel van een verandering in het denken over professionele ontwikkeling: van 'going for courses' (nadruk op participatie) naar learning (nadruk op actieve betrokkenheid bij het leerproces). Beginnende leraren vinden samenwerking met senior, leader en master teachers in professionele leergemeenschappen een zeer nuttige vorm van professionele ontwikkeling. De schooloverstijgende netwerken op de AST helpen om nieuwe dingen te leren, maar de grootste slag wordt volgens de leraren 
gemaakt bij het toepassen van de leerstof in de praktijk op de eigen school. Daarin spelen de professionele leergemeenschappen een belangrijke rol. Daarnaast kunnen leraren conferenties bezoeken als onderdeel van hun professionele ontwikkeling.

\section{Online samenwerking}

Leraren participeren in online samenwerking die wordt gefaciliteerd door het OPAL-systeem. OPAL staat voor 'one portal, all learners' en is een digitaal platform waar leraren materialen (b.v. lesplannen), bronnen (b.v. onderzoeksrapporten) en ervaringen met elkaar kunnen delen. OPAL wordt ook als discussie- en evaluatieplatform gebruikt door leraren die eenzelfde nascholing hebben gevolgd en met elkaar willen reflecteren op hun ervaringen met de implementatie van de kennis en vaardigheden die ze in de cursus hebben opgedaan.

\section{Work attachment programmes}

Tot slot kunnen leraren participeren in zogeheten work attachment programma's, waarin ze 2 tot 10 weken kunnen meelopen bij een andere organisatie en tijdelijk een andere functie kunnen uitoefenen. Deze programma's worden ook vaak gebruikt als een soort try out, om uit te vinden of een bepaalde functie of taak bij een leraar zou passen. Het Ministerie van Onderwijs biedt zelf work attachments aan, maar scholen zetten ook zelf samenwerkingsverbanden met bedrijven en organisaties in hun eigen omgeving op, om te waarborgen dat de work attachment programmes goed aansluiten bij de praktijk en visie van de school.

\section{GESTANDAARDISEERDE TRAJECTEN}

Leraren maken jaarlijks in overleg met de school een keuze uit het ruime aanbod aan losse en kortdurende cursussen, afgestemd op hun leerwensen en -behoeftes van dat moment. Hoewel sommige cursussen met name geschikt lijken voor leraren in een bepaalde track, komt het veelvuldig voor dat een leraar in de Teaching Track bijvoorbeeld cursussen volgt die meer gelinkt zijn aan de Senior Specialist Track. In die zin is professionele ontwikkeling niet rechtstreeks gekoppeld aan de loopbaanladder van leraren. Evenzo geldt dat iemand die niet verder opklimt evenveel tijd investeert aan zijn professionele ontwikkeling als iemand die actief bezig is om op te klimmen langs de loopbaanladder. Het wordt als onwenselijk gezien als leraren professionele ontwikkeling zien als een middel om promotie te maken (zie ook hoofdstuk 5). Om die reden is er geen sprake van een één-op-één relatie tussen professionele ontwikkeling en promotiekansen. Er zijn echter enkele meer gestandaardiseerde scholingstrajecten, die weldegelijk een directe link hebben met verschillende treden op de loopbaanladder van leraren. Deze worden hieronder beschreven.

\section{Master of PhD}

Steeds meer Singaporese leraren volgen een Master. Een master-graad is een voorwaarde om in te stromen in de Senior Specialist Track, voor de andere twee tracks geldt deze voorwaarde niet. Het behalen van een Master-graad heeft in principe geen gevolgen voor de loopbaan van leraren. Toch stimuleert de overheid zittende leraren de laatste jaren actief om een Master te behalen en streeft men ernaar dat alle nieuw instromende leraren hun een master-graad behalen. Er zijn mogelijkheden om tijd en geld aan te vragen voor het volgen van een master-opleiding (zie onder 'kosten'), en leraren krijgen een bonus als zij een Master voltooien. Ook zijn er steeds meer scholen waar het min of meer gebruikelijk is dat alle docenten een master-diploma hebben. Een $\mathrm{PhD}$ voor leraren is niet gebruikelijk. Enkele onafhankelijke scholen die niet onder het Ministerie van Onderwijs vallen, hebben wel een lerarenteam met veel $\mathrm{PhD}$-opgeleiden. Leraren komen alleen in aanmerking voor financiering van een PhD-traject vanuit de overheid wanneer zij de Senior Specialist Track volgen. 


\section{Milestone programmes}

Naast losse cursussen en de mogelijkheid een Master te behalen, kent Singapore enkele langere nascholingsprogramma's met een vastliggend curriculum, de zogeheten Milestone Programmes. Deze programma's zijn expliciet gekoppeld aan bepaalde functies op de loopbaanladder van leraren. De programma's zijn niet verplicht, maar in de praktijk worden leraren in de betreffende functie wel sterk aangemoedigd deze te volgen. Het voltooien van een milestone programma is geen ingangseis voor de functies waaraan deze gekoppeld zijn, maar geldt eerder als een 'beloning' voor een promotie. Het is gebruikelijk dat een leraar eerst promotie maakt, en vervolgens het bijbehorende milestone programma volgt. $\mathrm{Na}$ het voltooien van het programma wordt een leraar geacht nog minimaal een jaar de betreffende functie te bekleden. Een bijkomend voordeel van de milestone programma's is dat leraren via deze programma's in contact staan met andere leraren die in dezelfde fase van hun loopbaan zitten. Zeker in de hogere functies, waarin men minder collega's heeft met eenzelfde functie dan in lagere posities, wordt contact met leraren in dezelfde functie op andere scholen als zeer nuttig ervaren.

\section{Milestone programma's voor de Leadership Track}

Voor leraren in de Leadership Track zijn drie milestone programma's ontwikkeld. Dit zijn intensieve nascholingsprogramma's van 10 weken tot 6 maanden (fulltime), die alle door het NIE worden verzorgd. $\mathrm{Er}$ is een Leadership and Management Programme voor leraren die voor het eerst een rol van middle manager op zich nemen. Dit gaat meestal om subject/level heads en heads of department. Het Management and Leadership in Schools Programme wordt met name gevolgd door middle managers (meestal heads of department) die zich opmaken om hun taken te verbreden en verzwaren naar verantwoordelijkheden die hun eigen afdeling overstijgen. Het derde en meest intensieve programma is het Leaders in Education Programme, dat is gericht op vice principals en functionarissen op gelijksoortig niveau. Dit programma duurt zes maanden en wordt jaarlijks aangeboden aan 30 tot 40 geselecteerde leraren met een zeer goede track record, die bovendien enkele tests maken en een selectie-interview moeten doen alvorens te worden toegelaten. Het programma vormt daarmee min of meer een toegangspoort naar leiderschapsfuncties hoger dan het niveau van vice principal. Sinds kort is er een ook milestone programma ontwikkeld voor de nieuwe functie van school staff developers.

\section{Milestone programma's voor de Teaching Track}

Naar aanleiding van de uitbreiding van de Teaching Track (zie hoofdstuk 5), heeft het NIE drie opeenvolgende programma's van elk tien weken ontworpen voor leraren in deze track. Voor senior teachers met één tot vijf jaar ervaring is er het Teacher Leaders Programme 1, waarin vooral aandacht wordt besteed aan het ontwikkelen van kennis en vaardigheden die gericht zijn op de uitoefening van taken binnen de eigen schoolomgeving. Het Teacher Leaders Programme 2 is gericht op lead teachers en op senior teachers met meer dan zes jaar ervaring. In dit programma wordt gewerkt aan de ontwikkeling van kennis en vaardigheden gerelateerd aan de uitoefening van taken op zowel school- als clusterniveau. Het Teacher Leaders Programme 3 gaat komend jaar voor het eerst van start en is gericht op master teachers en op vice principals uit de Leadership Track die de overstap maken naar master teacher. De opbouw en scope van deze drie milestone programma's is direct gerelateerd aan het model dat is afgebeeld op pagina 13 .

\section{KEUZE VOOR ACTIVITEITEN}

\section{Keuze van de leraar}

Leraren stellen hun pakket aan nascholingsactiviteiten jaarlijks in overleg met hun reporting officer en de school staff developer (zie hieronder) samen. Daarbij is veel ruimte voor individuele keuzes en maatwerk. Leraren doen hiervoor jaarlijks een learning needs analysis (zie eveneens hieronder), en op sommige scholen moeten leraren zichzelf ranken op een aantal vaardigheden om te bepalen op welke punten zij zich zouden 
willen verbeteren. Er is in principe geen sprake van verplichte cursussen voor leraren op een bepaald functieniveau. Toch hanteren scholen in de praktijk vaak richtlijnen, bijvoorbeeld door accenten te leggen op bepaalde vaardigheden en leerdoelen voor leraren in verschillende fases van hun loopbaan, of door te verlangen dat alle functionarissen op een bepaald niveau een bepaalde scholing doorlopen. Leraren geven aan het prettig te vinden als er enige voorselectie voor hen is gedaan. Het helpt hen keuzes te maken uit het ruime aanbod, die passen bij hun loopbaanfase. Zij ervaren voldoende eigenaarschap met betrekking tot hun professionele ontwikkeling.

\section{Keuze van de school}

Naast de eigen keuzes die een leraar, in overleg met de school, maakt voor de besteding van zijn of haar tijd voor professionele ontwikkeling, kopen scholen regelmatig schoolbrede trainingen in, waar de hele staf aan deelneemt. Het voordeel van schoolbrede trainingen wordt gezocht in de gemeenschappelijke taal en aanpak die daarmee onder het lerarenteam ontstaat. Vaak wordt zo'n 30 tot 40 uur van de 100 uur die op jaarbasis beschikbaar is voor professionele ontwikkeling gevuld met activiteiten die door de school worden geïnitieerd en schoolbreed worden ingezet. Deze activiteiten hebben over het algemeen voorrang boven individuele keuzes voor nascholing die een leraar maakt. De ervaring is dat deze elkaar zelden in de weg zitten, omdat er genoeg tijd overblijft voor individuele activiteiten van leraren. Schoolleiders geven de voorkeur aan in-company trainingen, omdat deze zo dicht mogelijk bij de eigen lespraktijk kunnen worden gepositioneerd. Een deel van de tijd die schoolbreed wordt ingezet voor professionele ontwikkeling wordt gebruikt voor, meestal wekelijkse, bijeenkomsten van professionele leergemeenschappen, waarin leraren opgedane kennis en ideeën met elkaar delen.

Schoolleiders organiseren een schoolbrede dialoog over de leerbehoeften van het lerarenteam, en gebruiken surveys onder leraren en leerlingen om de leerbehoeften en -benodigdheden op schoolniveau in kaart te brengen. De ervaringen met schoolbrede cursussen zijn daardoor meestal goed. Leraren geven aan dat er natuurlijk ook weleens cursussen tussen zitten die minder aansluiten bij hun eigen leervragen. Met name wekelijkse presentaties in professionele leergemeenschappen hebben niet altijd evenveel prioriteit voor de leraren, wat laatkomen en gebrek aan concentratie met zich meebrengt. Zowel enkele leraren als schoolleiders zetten in de interviews vraagtekens bij de huidige nadruk op professionele leergemeenschappen. Toch worden deze uurtjes in z'n algemeenheid als nuttig ervaren, omdat er onderwerpen langskomen waar een leraar uit zichzelf misschien minder snel mee in aanmerking zou zijn gekomen. Soms leidt zo'n ervaring tot de keuze van een leraar om zelf een training of cursus te volgen over een thema dat in de professionele leergemeenschap is behandeld.

\section{De reporting officer}

Elke leraar heeft een reporting officer, meestal de head of department of subject head, die de ontwikkeling en het functioneren van de leraar volgt en met hem of haar meedenkt over nut en noodzaak van bepaalde vormen van professionalisering. Ook functionarissen in hogere functies hebben een reporting officer: voor een principal is dat bijvoorbeeld de cluster superintendent. De leraar en de reporting officer bespreken minimaal twee keer per jaar het functioneren van de leraar en de plannen voor de komende periode. Daarbij wordt expliciet stilgestaan bij de loopbaanplannen van de leraar en de behoeften op het gebied van professionalisering. De reporting officer is ook betrokken bij de jaarlijkse beoordeling van het functioneren van de leraar, die bepalend is voor de ranking en prestatiebonus van leraren. Het is niet mogelijk een goede beoordeling te krijgen wanneer er niet in professionele ontwikkeling is geïnvesteerd.

\section{De school staff developer}

Sinds 2009 is een nieuwe functie geïntroduceerd die onderdeel uitmaakt van de Leadership Track en in de hiërarchie op gelijk niveau staat met de functie van head of department. de functie van school staff developer (SSD). De SSD vormt de spil in de professionele ontwikkeling van leraren. Voorheen vielen de taken van de SSD onder de vice principal. De SSD is betrokken bij het rekruteren van leraren en plant, organiseert, en 
faciliteert de professionele ontwikkeling van alle schoolmedewerkers, zowel op schoolniveau als op individueel niveau. De SSD bespreekt met de vice principal en principal welke scholing het lerarenteam nodig heeft en organiseert dat deze scholing plaatsvindt (meestal in-company). Hiervoor worden driejarenplannen opgesteld, die na twee jaar worden geëvalueerd en eventueel bijgesteld. Daarnaast bekijkt de SSD samen met de heads of department welke professionaliseringsbehoeften er binnen de teams bestaan. De heads of department bepalen dit op hun beurt aan de hand van gesprekken met hun teams. Tot slot bespreekt de SSD drie keer per jaar met elke docent in de school zijn of haar ontwikkelingsbehoeften. De leraar en de SSD doen daarvoor een zogeheten learning needs analysis. Daarbij wordt gekeken of er nog bepaalde leemten zijn in de kennis en vaardigheden van een leraar en welke wensen en behoeftes de leraar heeft op het vlak van professionalisering. Wanneer een leraar bepaalde loopbaanplannen heeft, bekijken de leraar en SSD samen of de leraar bepaalde professionaliseringstrajecten kan volgen die helpen een geschikt portfolio op te bouwen, om zo meer kans op promotie naar de gewenste functie te maken. De reporting officers leveren eveneens input aan de SSD over de leer- en ontwikkelingsbenodigdheden van leraren.

SSD's verschillen in de mate waarin zij sturing geven aan de professionele ontwikkeling van leraren. Sommigen laten het helemaal open, waar anderen een bepaalde set cursussen en activiteiten vaststellen die zij nodig achten voor bepaalde functies. Ook ontwikkelen sommige SSD's bepaalde routes door het teacher growth model, waarbij accenten worden gelegd op bepaalde leerdoelen, of bepaalde cursussen prioriteit krijgen. Dergelijke routes kennen vaak een opbouw, die leraren de kans biedt om langzaamaan meer senior-taken op zich te nemen. Dit biedt de leraar en de school de kans om te bekijken of de leraar geschikt zou zijn om door te groeien naar een senior-functie. Meestal stemmen SSD's van verschillende scholen binnen eenzelfde cluster deze routes met elkaar af.

Sommige SSD's kiezen ervoor om niet betrokken te zijn bij de beoordeling van leraren, om te waarborgen dat zij een vertrouwensrelatie kunnen opbouwen met leraren. $\mathrm{Zij}$ willen dat een leraar zich volledig vrij voelt ook te bespreken wat er niet goed gaat, zonder bang te hoeven zijn dat dit de beoordeling nadelig beïnvloedt. Leraren geven eveneens aan behoefte te hebben om hun groei te kunnen bespreken zonder dat dit gepaard gaat met een beoordeling. Er zijn echter ook SSD's die wel betrokken zijn bij de beoordeling van het functioneren van leraren. Naast het bespreken en faciliteren van professionele ontwikkelingsplannen van individuele leraren, is de SSD actief betrokken bij het monitoren van het welzijn en de tevredenheid van de leraren op de school en bij het evalueren van de opbrengsten van de nascholingsactiviteiten.

\section{TIJD VOOR PROFESSIONELE ONTWIKKELING}

\section{0 uur per jaar}

Elke leraar in Singapore heeft recht op 100 uur professionele ontwikkeling per jaar. Scholen moeten leraren verplicht 1 uur per week vrij roosteren voor professionele ontwikkeling, maar in de praktijk wordt er meestal 2 uur per week vrijgeroosterd, waarvan op veel scholen één uur opgaat aan wekelijkse bijeenkomsten van professionele leergemeenschappen. Vaak wordt zo'n 30 tot 40 uur van de 100 uur gevuld met activiteiten die door de school worden geïnitieerd en schoolbreed worden ingezet. De rest van de tijd wordt in overleg tussen leraar en school ingevuld (zie hierboven).

\section{Tijd vrijmaken}

Leraren regelen meestal onderling de opvang van elkaars lesuren wanneer iemand een of enkele uurtjes moet worden vervangen wegens deelname aan nascholingsactiviteiten. Desgevraagd geven leraren aan deze zogeheten relief teaching over het algemeen geen probleem te vinden. Het gaat meestal maar om losse uurtjes of korte periodes, men gunt elkaar de uren en men heeft er zelf ook baat bij als anderen hun lessen incidenteel opvangen. Wanneer een leraar vaker of langer moet worden vrijgeroosterd, of wanneer er veel leraren tegelijk afwezig zijn, dan kan de school een beroep doen op een pool van extra leraren die kunnen 
worden ingezet om de leraar te vervangen. Wanneer leraren een volledig master-programma willen volgen, of een andere langdurige cursus, kunnen zij een aanvraag bij het Ministerie indienen voor een study leave. Deze wordt niet vanzelf gehonoreerd, maar dient goed onderbouwd te worden. Soms eist een school dat een leraar die tijd en financiering krijgt om een master-programma te volgen daarna nog enkele jaren binnen de school blijft werken.

Wie 12 jaar in het vak zit, krijgt standaard een professional development leave van 10 weken. Leraren die geselecteerd worden voor het Leaders in Education Programme, een intensief trainingsprogramma van zes maanden (zie hierboven) verlaten hun school en positie voor het volgen van het programma volledig. Zij worden na voltooiing van hun programma in een nieuwe functie geplaatst.

Uiteraard kan niet elke leraar op ieder moment in het schooljaar zomaar lessen opgeven voor professionele ontwikkeling. Leraren moeten tijdig aangeven welke wensen en plannen zij hebben. Meestal maakt men aan het begin van het schooljaar een planning. De school staff developer bekijkt vervolgens welke mogelijkheden er zijn en probeert de leraar vrij te roosteren. Leraren weten goed welke periodes in het schooljaar de zogeheten 'gouden periodes' zijn dat nascholing beter is in te passen, en proberen daar rekening mee te houden bij het maken van hun plannen.

\section{KOSTEN VAN PROFESSIONELE ONTWIKKELING}

\section{Kosten voor de leraar}

Voor leraren zijn er geen kosten verbonden aan nascholingsactiviteiten. De kosten voor cursussen die via het AST worden angeboden, worden door de overheid gedekt. Het budget hiervoor is jaarlijks zo'n 8 miljoen Singaporese dollar (zo'n $5^{1} / 2$ miljoen euro). Het budget wordt de laatste jaren niet volledig besteed, doordat er meer online wordt gewerkt en er in toenemende mate wordt gewerkt met leergemeenschappen en kennisnetwerken via de AST. Deze worden door de leraren zelf verzorgd en kosten de overheid daarmee in feite niets extra. Leraren die een Master volgen, bekostigen deze soms wel gedeeltelijk of volledig zelf, al bestaan hier ook beurzen voor (zie hieronder).

\section{Schoolfonds}

Scholen beschikken over een staff training fund waaruit overige scholingskosten worden betaald, bijvoorbeeld wanneer een cursus door een andere aanbieder dan via AST/NIE wordt verzorgd. Scholen hebben zo'n 300 Singaporese dollar (200 euro) per docent per jaar beschikbaar. Als een school een grootschalige training inkoopt, bijvoorbeeld een meerdaagse cursus voor een hele school, moet hiervoor een tender worden uitgeschreven, aangezien het om besteding van publiek geld gaat.

\section{Scholarships en study leaves}

De overheid biedt competitieve scholarships aan voor het bekostigen van master-opleidingen en studiereizen, waarvoor leraren een aanvraag kunnen indienen. Ook kunnen leraren meedingen naar een study leave. Veel leraren die een Master volgen, doen dat parttime en bekostigen deze zelf, met een deel subsidie vanuit de overheid. Wie een fulltime master volgt, bekostigt dit meestal met een scholarship én een study leave. Voor een $\mathrm{PhD}$ komen leraren alleen nog in aanmerking voor een scholarship van de overheid als ze daarna de Senior Specialist Track instromen.

\section{EVALUATIE OPBRENGSTEN PROFESSIONELE ONTWIKKELING}

De opbrengsten van nascholing worden primair kwalitatief geëvalueerd. Leraren evalueren cursussen in TRAISI (zie begin van dit hoofdstuk), al geven SSD's en leraren aan dat dit niet altijd gebeurt. Meestal vragen SSD's leraren voorafgaand aan een cursus leerdoelen te formuleren. Twee weken na de cursus wordt hen gevraagd te evalueren of de leerdoelen zijn gerealiseerd en of ze het idee hebben dat ze kennis 
en vaardigheden hebben opgedaan die ze kunnen gebruiken in hun lessen. Naar aanleiding van deze evaluatie ontwikkelt de leraar samen met de reporting officer een plan voor toepassing van de opgedane kennis en vaardigheden in de lessen. Vervolgens wordt de leraren gevraagd na drie maanden opnieuw te reflecteren op de toepasbaarheid van het geleerde. Soms worden bovengenoemde evaluaties niet op individueel, maar op groepsniveau ingevuld, om de papierwinkel te beperken. Er bestaat sowieso enige weerzin tegen teveel van dit soort 'papieren' evaluaties, zowel van de kant van leraren als van de kant van schoolleiders. Men geeft er de voorkeur aan om in de praktijk te verkennen of een scholing effectief is geweest. Schoolleiders vragen leraren naar hun ervaringen en er worden informele sharing meetings georganiseerd, waar leraren opgedane kennis en ideeën met elkaar delen. Soms nemen heads of department, die meestal als reporting officer van een leraar functioneren, een kijkje in de klas van een leraar, om te zien of hij of zij het geleerde toepast, waarna hier desgewenst een gesprek over plaatsvindt. Ook laten SSD's leraren in de professionele leergemeenschappen op de school reflecteren op de leeropbrengsten en toepassing van een nascholing. In de leergemeenschappen delen leraren de opgedane kennis en vaardigheden van verschillende trainingen met elkaar. Daarnaast zetten SSD's schoolbrede enquêtes uit onder leerlingen, waarmee zij een vinger aan de pols houden wat betreft de effecten van schoolbrede nascholingsactiviteiten. Wanneer er bijvoorbeeld schoolbreed is ingezet op nascholing over de omgang met pesten, dan zorgt de SSD dat er in de enquête onder leerlingen getoetst wordt of er inderdaad minder gepest wordt, of dat leraren in de ogen van de leerlingen anders/beter op pesten reageren dan voorheen. 


\section{Verkenning leerpunten:}

\section{wat kan Nederland leren van Singapore?}

\section{Koppeling met de Lerarenagenda 2013-2020}

In de Lerarenagenda 2013-2020 zijn verschillende actiepunten opgenomen die gericht zijn op de professionele ontwikkeling van leraren. De visie op de 'leraar 2020' die daarbij wordt geschetst, wordt bepaald door drie dimensies: een goede opleiding; blijvende bekwaamheid; en een antrekkelijk carrièreperspectief (Lerarenagenda, p. 30). De eerste dimensie, een goede (initiële) opleiding van leraren, valt buiten bestek van dit rapport. De tweede en derde dimensie, blijvende bekwaamheid en een aantrekkelijk carrièreperspectief, vormen de kapstok aan de hand waarvan de bruikbaarheid en aantrekkelijkheid van (aspecten van) het Singaporese model voor de Nederlandse context worden verkend.

Blijvende bekwaamheid wordt in deze analyse geïnterpreteerd als de doelstelling dat leraren continu en actief werken aan hun professionele ontwikkeling (Lerarenagenda, p. 25). Het antrekkelijk carrièreperspectief is in de analyse uitgesplitst naar twee gerelateerde doelstellingen: de horizontale en de verticale versterking van de loopbaanladder van leraren. Met horizontale versterking wordt bedoeld het bieden van ruimte voor verbreding van de expertise en inzetbaarheid van leraren. Deze doelstelling is gerelateerd aan de wens, onder meer geformuleerd in het pamflet Samen Leren (2014) en het rapport van de Commissie Leraren (2007), om meer functiedifferentiatie aan te brengen binnen het leraarschap, opdat leraren de mogelijkheid krijgen alternatieve carrièrepaden te bewandelen en het lesgeven te combineren met andere rollen en taken. In de Lerarenagenda wordt in dit licht onder meer gerefereerd aan de hybride docent', de mogelijkheid voor gecombineerde banen in samenwerking met het bedrijfsleven, en mogelijkheden voor leraren om onderzoeksvaardigheden op te doen die zij vanuit een aantrekkelijke positie in de schoolorganisatie kunnen inzetten (zie ook: Ministerie van OCW, 2014). Met verticale versterking wordt bedoeld het versterken van het carrièreperspectief voor aankomende en zittende leraren aan de hand van antrekkelijke loopbaanroutes met mogelijkheden voor promotie naar hogere functies (Lerarenagenda, p. 22). Hierbij kan gedacht worden aan betere doorgroeimogelijkheden voor leraren, kansen voor promotie naar meer senior functies en taken, en een bijbehorende ontwikkeling in salariëring.

Per doelstelling wordt eerst een theoretische analyse weergegeven van de mogelijke bruikbaarheid en aantrekkelijkheid van het Singaporese model vanuit het perspectief van de Nederlandse context, waarna de reflecties worden besproken die naar voren kwamen in dialoog met Nederlandse stakeholders. In de slotparagraaf wordt tot slot een overkoepelende indruk van de belangrijkste leerpunten van het Singaporese model voor de Nederlandse context geschetst.

\section{DOELSTELLING 1: BLIJVENDE BEKWAAMHEID}

\section{Theoretische verkenning}

De loopbaanladder van leraren in Singapore is als zodanig geen instrument om de bekwaamheid van leraren te bevorderen. Deelname aan programma's voor professionele ontwikkeling leidt bijvoorbeeld niet direct tot hogere functies. Met deze formele ontkoppeling wil men in Singapore voorkomen dat leraren enkel deelnemen aan professionaliseringstrajecten om hogerop te kunnen komen. Over een dergelijk mechanisme bestaan in Nederland eveneens zorgen. Naar aanleiding van de recente massale deelname aan master-opleidingen wordt de vraag opgeworpen of sommige leraren niet meer bezig zijn met het behalen van een papiertje dan aan het bevorderen van hun bekwaamheid (zie onder meer: Lucassen \& van de 
Meent, 2015). Een zekere mate van ontkoppeling tussen professionele ontwikkeling en promotiekansen lijkt in dat licht verstandig.

Het is veeleer de wijze waarop professionele ontwikkeling in Singapore wordt verbonden met de loopbaanladder van leraren, waar Nederland van zou kunnen leren. Leraren werken aan hun portfolio in aanloop naar de instroom in één van de drie tracks, en zorgen dat zij hun kennis en vaardigheden zodanig ontwikkelen dat zij op kunnen gaan voor een functie die zij ambiëren. Daarmee vormt de loopbaanladder een positieve prikkel tot investering in professionele ontwikkeling door leraren. Het is echter niet de enige prikkel. Meer nog vormt de prominente plaats die professionalisering in het dagelijks werk van leraren en in de scholen inneemt de aanjager. De wijze waarop leraren hierin gefaciliteerd en ondersteund worden, in termen van tijd en geld, maar bovenal in de wijze waarop zij vanuit de school ondersteund worden, maakt dat elke leraar in Singapore professionele ontwikkeling als een vanzelfsprekendheid beschouwt. Uiteraard speelt ook het feit dat professionele ontwikkeling meetelt in de evaluatie en prestatiebonus van leraren hierin mee. Desondanks lijkt Singapore erin geslaagd professionele ontwikkeling niet als een 'moetje' te positioneren, maar als een recht waar leraren graag gebruik van maken. Het feit dat deelname aan een van de milestone programmes wordt gezien als een beloning voor het bereiken van een bepaalde positie op de loopbaanladder, en daarmee voor gebleken kwaliteiten en motivatie, draagt bij aan het beeld dat professionele ontwikkeling vooral een kans biedt voor leraren die gemotiveerd zijn het beste uit zichzelf te halen. Een vraag die hierbij overigens gesteld kan worden, is of Nederlandse scholen dezelfde investeringsbereidheid kennen ten aanzien van de professionalisering van leraren als Singaporese scholen, waar de scholen direct onder het Ministerie van Onderwijs vallen.

De uitgewerkte infrastructuur voor professionele ontwikkeling helpt leraren te bepalen aan welke vaardigheden zij in verschillende fases van hun loopbaan willen werken en welke vormen van professionalisering zij hiertoe kunnen aanwenden. Alle gesprekspartners in Singapore gaven aan dat vraagsturing essentieel is voor professionele ontwikkeling van leraren, maar dat vraagsturing pas effectief tot stand komt als er in een basisstructuur is voorzien. Zowel de loopbaanladder van leraren met de drie tracks als het Teacher Growth Model vormen routekaarten die leraren helpen om hun professionele ontwikkeling als leraar vorm te geven. Een interessant aspect van de wijze waarop professionele ontwikkeling vorm krijgt in Singapore, is het feit dat er gewerkt wordt met kortdurende programma's die zoveel mogelijk zijn toegesneden op de leervragen en loopbaanfase van de leraar. De focus op vraagsturing, de mogelijkheid jaarlijks een individueel nascholingspakket samen te stellen, en de sterke positionering van professionele leergemeenschappen binnen de scholen, dragen er alle aan bij dat professionele ontwikkeling direct ansluit bij de vragen waar een leraar in de huidige fase van zijn loopbaan mee te maken heeft.

\section{Reflecties Nederlandse stakeholders}

Ook door betrokkenen uit het Nederlandse onderwijsveld worden vraagtekens geplaatst bij de loopbaanladder van leraren als middel om de bekwaamheid van leraren te bevorderen. Maar men herkent eveneens de stimulerende werking die uitgaat van het Singaporese model, dat tevens als 'stok achter de deur' voor professionele ontwikkeling kan fungeren. In Nederland maken veel leraren niet optimaal gebruik van de tijd en ruimte die geboden wordt voor professionalisering. De koppeling aan uiteenlopende loopbaanpaden en doorgroeimogelijkheden kan een nuttige prikkel vormen voor leraren om duurzaam te investeren in professionele ontwikkeling.

Met name het gepersonaliseerde leren en de sterke vraagsturing met ruimte om professionaliseringsactiviteiten af te stemmen op de loopbaanfase van de leraar, worden door betrokkenen als leerpunt genoemd. Ook de routekaart die het model biedt, met duidelijk herkenbare paden die helpen richting te geven aan professionele ontwikkeling, wordt als een sterk punt van het Singaporese model gezien. Een digitale interface als TRAISI, die de leraar in staat stelt zicht te houden op de eigen professionele ontwikkeling, kan een belangrijke bijdrage leveren aan het creëren van meer eigenaarschap en richting in de professionele ontwikkeling van leraren. 
Een aantrekkelijk aspect, en in de ogen van de Nederlandse betrokkenen tevens een voorwaarde voor succes van het model, is het feit dat leraren in Singapore sterk ondersteund worden in hun professionalisering aan de hand van begeleidingsgesprekken. Enkele betrokkenen merken op dat, veel meer dan in Nederland, ontwikkelgesprekken voor leraren in Singapore écht nut hebben, omdat er directe actiepunten aan verbonden worden in termen van professionalisering. Hiermee wordt in de ogen van betrokkenen meer een 'cultuur van leren' gecreëerd, die bijdraagt aan de wil onder leraren om te streven naar blijvende bekwaamheid. Het ontwikkelingsperspectief voor leraren is daarmee zowel cultureel als structureel sterker verankerd in Singapore dan op dit moment in Nederland het geval is. Een kanttekening die hierbij wordt gemaakt is dat Singaporese leraren, vanwege de selectie aan de poort van de lerarenopleiding, wellicht beschikken over een relatief sterk ontwikkeld lerend en zelfregulerend vermogen dat hen in staat stelt optimaal gebruik te maken van een sterk vraaggestuurd model.

De kracht van het Singaporese model ligt volgens de betrokkenen primair in de keuze om te investeren in mensen: een leraar wordt niet alleen aangesproken op zijn verantwoordelijkheid om zijn bekwaamheid op niveau te houden, maar wordt hierin ook goed ondersteund in termen van begeleiding, tijd, geld en zeggenschap. In plaats van het inhuren van externe adviseurs door scholen, is de leraar in Singapore meer eigenaar van zijn eigen professionele ontwikkeling, en daarmee ook van die van de school. Door de vragen en problemen van de leraar en zijn onderwijspraktijk centraal te stellen, kan een leraar zich sterker identificeren met professionaliseringsactiviteiten en is de kans op effectiviteit van die activiteiten ook groter. Hiervan plukken de school en de leerlingen de vruchten. Ook stellen betrokkenen dat lerarenopleidingen en nascholingsinstituten op basis van een model naar Singaporees voorbeeld maatwerk-programma's zouden kunnen ontwikkelen voor verschillende loopbaanfasen en rollen binnen het leraarschap. Tot slot wordt opgemerkt dat aansluiting van nascholingsactiviteiten bij de loopbaanfase en rollen van leraren een nuttige insteek kan zijn bij de koppeling van professionele ontwikkeling aan het lerarenregister.

\section{DOELSTELLING 2: HORIZONTALE VERSTERKING LOOPBAANLADDER LERAREN}

\section{Theoretische verkenning}

De loopbaanladder biedt leraren expliciet de mogelijkheid zich te ontwikkelen in verschillende richtingen. Een dergelijk loopbaanmodel lijkt daarmee zeer geschikt voor het realiseren van deze doelstelling. De mogelijkheid om verschillende posities te kunnen uitproberen aan de hand van meeloopstages, verkennende trainingen en samenwerking met leraren uit verschillende tracks, biedt leraren de kans te ontdekken waar hun talenten liggen, alvorens hun loopbaan de gewenste richting uit te sturen. De mogelijkheid om horizontaal over te stappen, geeft leraren bovendien de ruimte om gaandeweg alsnog een andere koers te kiezen.

De Leadership Track is in Singapore sterk gepositioneerd, mede door de structurele behoefte aan schoolleiders. De indeling naar verschillende oplopende functies met bijbehorende scholing kan een belangrijke impuls geven aan de ontwikkeling van schoolleiders. Een vraag is in hoeverre een dergelijk pad nodig is in Nederland, in aanvulling op de bestaande leiderschapsposities en nascholingsprogramma's. De vernieuwde Teaching Track biedt een belangrijke mogelijkheid voor Singaporese leraren om hun loopbaan een impuls te geven zonder het lesgeven vaarwel te hoeven zeggen. De Specialist Track lijkt in de huidige vorm minder goed van de grond te komen in Singapore. Hoewel deze track mooie kansen zou kunnen bieden om de ontwikkeling van onderzoeksvaardigheden te stimuleren en leraren met dergelijke vaardigheden een passende positie te geven binnen de schoolorganisatie, is er in Singapore voor gekozen de specialisten buiten de scholen te plaatsen. Daarmee verlaten leraren in de Specialist Track de dagelijkse onderwijspraktijk, die voor velen juist een belangrijke motivatie vormt om leraar te worden. Wanneer Nederland leraren aan de hand van een gedifferentieerd loopbaanmodel zou willen stimuleren om zich te verbreden naar een meer onderzoekende rol, dan lijkt het verstandig om functies die lijken op die in de 
Specialist Track (deels) binnen de school te positioneren. Dit maakt deze functies vermoedelijk aantrekkelijker voor leraren en waarborgt bovendien dat de kennis en vaardigheden van specialisten hun weg vinden naar de onderwijspraktijk. Een andere optie zou zijn om dergelijke functies te integreren in een Teaching Track.

De Singaporese loopbaanladder van leraren biedt inspiratie om na te denken over het verbreden van carrièremogelijkheden voor leraren in de verschillende onderwijssectoren. Zo zou nagedacht kunnen worden over de ontwikkeling van een track voor leraren die hun werk in het onderwijs willen combineren met werken in het bedrijfsleven. Met name voor het beroepsonderwijs zou dit een relevante route kunnen vormen, die leraren de mogelijkheid biedt het lesgeven te combineren met werken in de beroepspraktijk zelf.

\section{Reflecties Nederlandse stakeholders}

Een loopbaanladder van leraren met verschillende routes biedt volgens de betrokkenen een geschikte insteek om de horizontale versterking van de loopbaanmogelijkheden voor leraren te realiseren. De Teaching Track lijkt bovendien een geschikt middel om leraren actiever te betrekken bij onderwijsontwikkeling, waardoor het pedagogisch leiderschap in de school sterker bij de leraar komt te liggen. Het expliciet maken van pedagogisch leiderschap middels de oplopende treden van de Teaching Track kan volgens betrokkenen leraren stimuleren om deze rol ook meer op zich te nemen. Ook zien betrokkenen kansen voor het steviger positioneren van de onderzoekende leraar in de school aan de hand van een meer horizontaal gedifferentieerde loopbaanladder voor leraren. Daarmee wordt een bredere inzetbaarheid van leraren gewaarborgd, wat tevens zou kunnen bijdragen aan de onderwijskwaliteit. Voorts vinden betrokkenen het aantrekkelijk dat de veelzijdigheid van het leraarschap in het Singaporese model beter zichtbaar worden gemaakt, en dat de verschillende taken en rollen van leraren expliciet onderdeel van de verschillende functies vormen. In Nederland vervullen leraren veel extra taken in hun eigen tijd, waardoor de verschillende kanten van het leraarschap minder zichtbaar én minder gewaardeerd worden. Een model met verschillende tracks schetst een minder eendimensionaal beeld van het leraarschap. Tot slot wordt opgemerkt dat een loopbaanladder met meer hybride functies voor leraren, zowel middels korte work attachments bij externe organisaties als via geformaliseerde taakomschrijvingen, een middel zou kunnen zijn om Nederlandse leraren de mogelijkheid te bieden om het leraarschap voor kortere of langere tijd te combineren met andere taken. Ook voor het bedrijfsleven zou dit een aantrekkelijke constructie kunnen zijn.

\section{DOELSTELLING 3: VERTICALE VERSTERKING LOOPBAANLADDER LERAREN}

\section{Theoretische verkenning}

De loopbaanladder van leraren vormt een routekaart voor aankomende en zittende leraren, die duidelijk aangeeft welke mogelijkheden er zijn voor leraren om zich na het begin van hun carrière verder te ontwikkelen binnen het onderwijs. De Singaporese loopbaanladder biedt richting en perspectief en lijkt daarmee een geschikt model om het carrièreperspectief van leraren te versterken. Leraren die al een tijdje in het onderwijs werken, kunnen aan de hand van de loopbaanladder toewerken naar meer verantwoordelijkheden en een hoger salaris. Het formaliseren van nieuwe verantwoordelijkheden en taken in een bijbehorende functie met passende salariëring kan een belangrijke motivatie voor leraren zijn om hun loopbaanontwikkeling binnen het onderwijs vorm te geven, in plaats van erbuiten. Voor ankomende leraren benadrukt een loopbaanmodel als dat van Singapore dat er tal van mogelijkheden zijn om carrière te maken binnen het leraarschap.

De koppeling met salariëring maakt het aantrekkelijk voor leraren om op te klimmen langs de loopbaanladder. De prestatiebonus die Singapore hanteert heeft overigens ook een tegengesteld effect, doordat leraren voorzichtig worden om andere taken of zwaardere verantwoordelijkheden op zich te 
nemen. Wie goed presteert in een bepaalde functie, kan minder happig zijn om een nieuwe functie uit te proberen waar hij of zij vermoedelijk in beginsel minder goed zal presteren. Een prestatiebonus bevordert de verticale doorstroom in die zin niet.

Een interessant aspect van het Singaporese model is de sterk ontwikkelde Teaching Track. Deze track biedt leraren de mogelijkheid een leiderschapsrol op zich te nemen zonder de kern van het leraarschap vaarwel te zeggen. De focus op pedagogisch leiderschap in deze track is een waardevolle toevoeging aan de vormen van leiderschap die in de Leadership Track centraal staan. In Nederland is een veelgehoorde klacht onder leraren dat wie meer verantwoordelijkheid wil en aankan, zich enkel in de richting van het schoolmanagement kan ontwikkelen. Een Teaching Track met verschillende oplopende posities voor pedagogisch leiderschap lijkt dan ook een kansrijk middel om getalenteerde leraren met passie voor het lesgeven te behouden voor het onderwijs.

De mogelijkheid om in Singapore op te klimmen langs de loopbaanladder is gerelateerd aan een sterke mobiliteit tussen scholen. Wie een trede hoger klimt, wisselt in veel gevallen van school. De mobiliteit tussen scholen ligt in Nederland lager. De vraag is of een bepaalde mate van mobiliteit nodig is om het loopbaanmodel goed te kunnen laten functioneren, en of die mogelijkheid in het Nederlandse bestel voldoende aanwezig is.

\section{Reflecties Nederlandse stakeholders}

Het zichtbaar maken van de veelzijdigheid van het leraarschap en doorgroeimogelijkheden voor leraren kan volgens betrokkenen een belangrijke bijdrage leveren aan het versterken van de status en aantrekkelijkheid van het beroep van leraar. De mogelijkheid in Singapore om te starten als classroom teacher met een beperkter aantal lesuren, om daarna langzaam door te groeien naar meer en/of andere verantwoordelijkheden, biedt aankomende en startende leraren een aantrekkelijk perspectief. Ook het feit dat de verticale stijging langs de loopbaanladder voor leraren in Singapore gepaard gaat met een uitgebreide infrastructuur van intensieve coaching en begeleiding, maakt het volgens betrokkenen voor potentiële en reeds werkzame leraren aantrekkelijker om (een voortzetting van) een loopbaan als leraar te overwegen. Met name de expliciete waardering van senior-taken die geen deel uitmaken van een schoolmanagement-functie met weinig tot geen lesgevende taken, wordt daarbij als een antrekkelijk aspect genoemd. De oplopende treden op de Singaporese ladder zorgen bovendien voor duidelijke rolmodellen. Jonge of aankomende leraren zien welke mogelijke posities er zijn voor leraren in uiteenlopende fases van hun loopbaan. Ze kunnen hierover in gesprek gaan met leraren op hogere posities, of een tijdje met ze meelopen, om te verkennen of een dergelijke rol ook iets voor hen zou zijn. De mogelijkheid voor meer verticale functiedifferentiatie binnen de beroepsgroep kan lerarenopleiders en nascholingsinstituten faciliteren bij het ontwerpen van gerichte professionaliseringsactiviteiten voor leraren in verschillende fases van hun loopbaan. Voor Nederland zou het volgens de betrokkenen zinvol zijn te verkennen hoe de treden op de loopbaanladder zouden kunnen worden gekoppeld aan de huidige functiemix. Daarbij wordt echter ook opgemerkt dat er in de beroepsgroep vooralsnog enige terughoudendheid is jegens een junior-medior-senior systeem voor leraren. Tot slot wordt door de betrokken stakeholders eveneens gewezen op het verschil tussen Nederland en Singapore wat betreft de tussenschoolse mobiliteit. Op dit moment blijven Nederlandse leraren soms 'hangen' op een school omwille van baanzekerheid, waarmee de mogelijkheden voor opwaartse mobiliteit van een leraar beperkt worden door de beschikbare vacatures binnen één school of schoolbestuur.

\section{CONCLUSIE}

Hierboven is besproken welke mogelijkheden een loopbaanladder van leraren naar Singaporees model zou kunnen bieden voor drie beleidsdoelstellingen uit de Nederlandse lerarenagenda. Per doelstelling is bekeken in welke mate (aspecten van) het Singaporese model geschikt en wenselijk zou(den) kunnen zijn om deze doelstellingen te realiseren. Hiertoe is een theoretische verkenning uitgevoerd op basis van de 
verzamelde gegevens en is een groep betrokkenen uit het Nederlandse onderwijs gevraagd te reflecteren op de kansen en knelpunten van het Singaporese model voor de Nederlandse context.

\section{Rationaliteit}

In termen van rationaliteit, de geschiktheid van het model als beleidsmiddel om bepaalde doelstellingen te realiseren, wordt op basis van deze eerste verkennende analyse geconcludeerd dat (1) het model als zodanig geen middel tot het bevorderen van blijvende bekwaamheid van leraren is, maar dat het model als kapstok voor de professionele ontwikkeling van leraren weldegelijk meerwaarde zou kunnen hebben; (2) het model kan bijdragen aan de horizontale versterking van de loopbaanladder van leraren door verschillende taken en rollen van leraren te formaliseren en zichtbaar te maken; en (3) het model kan bijdragen aan de verticale versterking van de loopbaanladder van leraren, mits er voldoende draagvlak onder de beroepsgroep bestaat voor een nadere hiërarchische functiedifferentiatie, en er voldoende ruimte is voor tussenschoolse mobiliteit om promotiekansen te kunnen waarborgen.

\section{Legitimiteit}

In termen van legitimiteit, de wenselijkheid van het model voor verschillende stakeholders, kan op basis van de reflecties van betrokkenen uit het Nederlandse onderwijsveld een aantal conclusies worden getrokken. Het model wordt om meerdere redenen wenselijk geacht voor leraren. Zowel de horizontale als verticale versterking van de loopbaanmogelijkheden biedt aantrekkelijke perspectieven voor leraren, waarbij met name ook de kansen om pedagogisch leiderschap sterker te verankeren in de carrièremogelijkheden voor leraren als een aantrekkelijk aspect worden gezien. Ten aanzien van de verticale versterking bestaat enige twijfel of er voldoende draagvlak is onder de beroepsgroep voor een nadere hiërarchische functiedifferentiatie. Voor lerarenopleiders en nascholingsinstituten zou de horizontale en verticale versterking eveneens kansen kunnen bieden om meer programma's op maat te maken die aansluiten bij de vragen en vereisten die voortkomen uit verschillende rollen en loopbaanfasen binnen het leraarschap. De horizontale versterking van de loopbaanladder van leraren wordt tevens als kans voor het bedrijfsleven genoemd, omdat deze mogelijkheden kan bieden voor het realiseren van combinaties tussen het leraarschap en werkzaamheden buiten het onderwijs. Dit zou kunnen bijdragen aan een betere aansluiting tussen onderwijs en de beroepspraktijk.

Voorts wordt de koppeling van professionele ontwikkeling aan de loopbaanfase van de leraar, en aan de vragen of problemen waar een leraar op een bepaald moment of in een bepaalde context tegenaan loopt, door betrokkenen als een wenselijk aspect van het Singaporese model gezien. De verwachting is dat professionaliseringsactiviteiten door deze vraagsturing meer kunnen bijdragen aan onderwijsverbetering, waarvan scholen en leerlingen de vruchten kunnen plukken. Wel kan de investeringsbereidheid onder scholen wellicht minder sterk zijn in Nederland, omdat een overstap van een leraar naar een andere school sterker als een verlies voor een school kan worden ervaren dan in Singapore, waar het scholenstelsel meer als één geheel functioneert.

\section{Overkoepelend leerpunt}

Los van de vraag in hoeverre verschillende aspecten van het Singaporese model aansluiten bij enkele beleidsdoelstellingen die het Nederlandse onderwijs zichzelf heeft gesteld, komt uit de dialoog met Nederlandse stakeholders naar voren dat de aantrekkelijkheid van het Singaporese model primair zit in de integrale aanpak. De ervaring is dat in Nederland beleid wordt gevoerd op verschillende deelterreinen rond de professionele ontwikkeling van leraren, maar dat de aanpak versnipperd is. Singapore heeft in de ogen van betrokkenen een heldere, integrale visie op de beroepsgroep van leraren ontwikkeld, van waaruit leraren op verschillende vlakken gestimuleerd worden in hun ontwikkeling. In Nederland wordt op uiteenlopende manieren gewerkt aan doelstellingen die raakvlakken hebben met het Singaporese model. Soms gaat dat om expliciete plannen en duidelijk zichtbaar beleid, soms speelt dit zich meer onder de oppervlakte af. De verschillende beleidsmaatregelen zijn in Nederland in de ogen van betrokkenen echter 
onvoldoende met elkaar verbonden. Het ontwikkelen van een meer integrale visie op de professionele ontwikkeling van leraren wordt daarom als het belangrijkste leerpunt voor Nederland genoemd. Volgens de betrokkenen zou een logische vervolgstap zijn om met een bredere groep stakeholders in kaart te brengen wat er al gebeurt in het veld, en op welke vlakken er nog hiaten of knelpunten zijn die met nieuw beleid, mogelijk naar voorbeeld van het Singaporese model, zouden kunnen worden aangepakt.

\section{Tot slot}

Dit onderzoek schetst een overkoepelend beeld van verschillende facetten van het Singaporese model en van ervaringen met het model in de praktijk. Het biedt tevens een verkenning van mogelijke leerpunten voor Nederland. Een model dat functioneert in een bepaalde context, zal nooit integraal kunnen worden geïmplementeerd in een andere context. Dat is uiteraard ook niet de insteek van deze verkenning. Mocht de hierboven voorgestelde voortzetting van de dialoog met een bredere groep stakeholders leiden tot de keuze om op bepaalde punten beleid te ontwikkelen naar Singaporees voorbeeld, dan is het raadzaam het model op deze punten aan een gedetailleerdere analyse te onderwerpen. Daarbij zal in elk geval aandacht moeten worden besteed aan een nadere uitwerking van de rollen van verschillende actoren, implementatieprocessen, randvoorwaarden voor het functioneren van het model, inbedding in het bredere onderwijsstelsel en de rol van aanpalend beleid.

De analyses in dit hoofdstuk laten zien dat het Singaporese model op verschillende vlakken inspiratie kan bieden om de professionele ontwikkeling van Nederlandse leraren te versterken, zowel in termen van bekwaamheid als in termen van loopbaanmogelijkheden. Het model zou op een aantal punten tegemoet kunnen komen aan knelpunten die op dit moment in Nederland worden ervaren. Het is daarom raadzaam de dialoog naar aanleiding van de bevindingen in dit rapport met een bredere groep betrokken voort te zetten, om nader te concretiseren hoe de geïdentificeerde leerpunten zouden kunnen worden uitgewerkt voor de Nederlandse beleidsagenda. 


\section{Bijlage 1: gesprekspartners in Singapore}

- Dhr. Tiong-San Teoh (Deputy Director, Standards \& Research Branch, Academy of Singapore Teachers), in samenwerking met:

- Mw. Monica Woei Ling Ong (leraar en tijdelijk. Academy Officer, Standards and Research Branch, Academy of Singapore Teachers)

o Mw. Yen Ching Chua-Lim (Deputy Director-General of Education (Professional Development) and Executive Director, Academy of Singapore Teachers)

- Dhr. Christopher Foo Programme Manager, Office of Graduate Studies and Professional Learning, National Institute of Education), in samenwerking met:

o Mw. Tan Aik Ling (Associate Professor \& Sub-Dean Professional Development, Office of Graduate Studies and Professional Learning, National Institute of Education)

o Dhr. Chew-Hung Chang (Associate Professor \& Associate Dean, Professional Development, Office of Graduate Studies and Professional Learning, National Institute of Education)

- Dhr. Pak Tee Ng (Associate Professor \& Associate Dean Leadership Learning, Office of Graduate Studies and Professional Learning, National Institute of Education)

- Dhr. Krishnan Aravinthan (Principal, Spectra Secondary School, Leadership Track)

- Mw. Nicole Liaw (School StaffDevelopment Officer, St Anthony's Canossian Secondary School), in samenwerking met:

o Mw. Caroline Sng (leraar en tijdelijk Academy Officer, Standards and Research Branch, Academy of Singapore Teachers)

- Mr. Raymond Bong (School Staff Development Officer, Rosyth Primary School), in samenwerking met:

o Mw. Audrey Lim (leraar en tijdelijke. Academy Officer, Standards and Research Branch, Academy of Singapore Teachers)

- Mw. Asmah Beevi Kamaludin (leraar in Teaching Track)

- Mw. Hanyou Loh (leraar, nog geen track gekozen)

- Mw. Jing Yng Ng (onderwijsjournalist, Mediacorps Press Ltd) 


\section{Bijlage 2: gesprekspartners in Nederland ${ }^{1}$}

Mw. Jolanda Berendrecht

Dhr. Frank Cörvers

Mw. Régie Driessen

Mw. Malika Habouria

Dhr. Wouter van Joolingen

Mw. Annet Kil

Mw. Bernie Kooistra

Dhr. Leo de Kraker

Mw. Anne van der Lingen

Dhr. Jules Pieters

Dhr. Erwin Rog

Dhr. Rien Rouw

Mw. Saskia Rijghard

Dhr. Wouter van der Schaaf

Mw. Aly Smelt - Medendorp

Mw. Ruth van Sommeren

Mw. Annette Sonnenberg

Dhr. Lex Stomp

Dhr. Bas de Wit
Ministerie van OCW

$\mathrm{ROA}$

HAN

CNV Onderwijs

Universiteit Utrecht

Onderwijscoöperatie

Kritische Vrienden Lerarenagenda

Kritische Vrienden Lerarenagenda

Ministerie van OCW

VELON (via e-mail)

VO-Raad

Ministerie van OCW

Ministerie van OCW

$\mathrm{AOb}$

HAN

Voorlopers Lerarenagenda, Hogeschool Leiden

Ministerie van OCW

Hogeschool Windesheim

VO-Raad

1 Vertegenwoordigers van de PO-Raad en MBO Raad waren helaas verhinderd voor de bijeenkomst. Zij zullen in het vervolgtraject opnieuw worden benaderd voor een dialoog n.a.v. het rapport. 


\section{Aangehaalde literatuur}

Commissie Leraren (2007). LeerKracht! Advies van de Commissie Leraren. Den Haag: Ministerie van OCW.

Cörvers, F. (2014). De arbeidsmarkt voor leraren: theorie, beleid en werkelijkheid. Inaugurele rede Tilburg University. Tilburg: PrismaPrint.

Centraal Planbureau (2014). Verkenning ophoging masters PO en VO. Den Haag: CPB.

Diverse auteurs (2014). Pamflet Samen leren: aanbevelingen uit het onderwijs. gedownload via http://www.vosabb.nl/wp-content/uploads/2014/09/Samen-leren.pdf op 1 oktober 2014.

Evers, G.H.M. (2007). Advies omtrent bevordering implementatie functie- en beloningsdifferentiatie in PO, VO en BVE. Tilburg: OSA.

Gerrichhauzen, J. (2007). De lerende en onderzoekende docent. Heerlen: Open Universiteit.

Goodwin, A. L. (2014). Perspective on high-performing education systems in Finland, Hong Kong, China, South Korea, and Singapore: what lessons for the U.S.? in: S. K. Lee, W.O. Lee \& E.L. Low (red). Educational policy innovations: levelling up and sustaining educational achievement. Singapore: Springer.

Hoogerwerf, A. (2008). Beleidsvoorbereiding: het ontwerpen van beleid. in: A. Hoogerwerf \& M.

Herweijer (red.) Overheidsbeleid. Een inleiding in de beleidswetenschap. Alphen aan den Rijn: Kluwer.

Inspectie van het Onderwijs (2013). Professionalisering als gerichte opgave. Verkennend onderzoek naar het leren van leraren. Utrecht: Inspectie van het Onderwijs.

Inspectie van het Onderwijs (2014). Onderwijsverslag 2012/2013. Utrecht: Inspectie van het Onderwijs.

IVA Beleidsonderzoek en advies (2012). Tijd voor (na)scholing. Tilburg: IVA.

Liew, W. M. (2012). Perform or else: the performative enhancement of teacher professionalism. Asia Pacific Journal of Education 32 (3), pp. 285-303.

Lucassen, M. \& van de Meent, Y. (2015). Masters zijn geen betere meesters. Vrij Nederland, 15 april 2015.

Minister van Onderwijs, Cultuur en Wetenschap (2014). Werken in het onderwijs. Kamerbrief 27.923 nr. 189, Tweede Kamer der Staten-Generaal.

Minister van Onderwijs, Cultuur en Wetenschap (2014). Vaststelling van de begrotingsstaten van het Ministerie van Onderwijs, Cultuur en Wetenschap (VIII) voor het jaar 2014. Kamerstuk 33.750 VIII nr. 118, Tweede Kamer der Staten-Generaal.

Ministerie van Onderwijs, Cultuur en Wetenschap (2008). Definitief akkoord Convenant Leerkracht van Nederland. Scheveningen: Ministerie van OCW.

Ministerie van Onderwijs, Cultuur en Wetenschap (2013). Lerarenagenda 2013-2020: de leraar maakt het verschil. Den Haag: Ministerie van OCW.

Ministerie van Onderwijs, Cultuur en Wetenschap (2014). Voortgangsrapportage lerarenagenda. Den Haag: Ministerie van OCW.

Ng, P. T. (2013). Developing Singapore school leaders to handle complexity in times of uncertainty. Asia Pacific Education Review (14), pp. 67-73.

OECD (2013). PISA 2012 results (volume I). Parijs: OECD.

OECD (2014). TALIS 2013 results. Parijs: OECD.

Onderwijsraad (2013). Kiezen voor kwalitatief sterke leraren. Den Haag: Onderwijsraad.

Teo, C.H. (2011). Speech voor de Teachers Investiture Ceremony, 4 juli 2001. Geraadpleegd via http://www.moe.gov.sg/media/speeches/2001/sp04072001.htm 